\title{
Manganese and iron reduction dominate organic carbon oxidation in surface sediments of the deep Ulleung Basin, East Sea
}

\author{
Jung-Ho Hyun ${ }^{1}$, Sung-Han Kim ${ }^{1}$, Jin-Sook Mok ${ }^{1}$, Hyeyoun Cho ${ }^{1}$, Tongsup Lee ${ }^{2}$, Verona Vandieken ${ }^{3}$, and \\ Bo Thamdrup ${ }^{4}$ \\ ${ }^{1}$ Department of Marine Science and Convergence Engineering, Hanyang University, 55 Hanyangdaehak-ro, Ansan, \\ Gyeonggi-do 15588, South Korea \\ ${ }^{2}$ Department of Oceanography, Pusan National University, 2 Busandaehak-ro, Busan, 46241, South Korea \\ ${ }^{3}$ Institute for Chemistry and Biology of the Marine Environment, University of Oldenburg, Carl-von-Ossietzky-Str. 9-11, \\ 26129 Oldenburg, Germany \\ ${ }^{4}$ Nordic Center for Earth Evolution, Department of Biology, University of Southern Denmark, Campusvej 55, \\ 5230 Odense M, Denmark
}

Correspondence to: Jung-Ho Hyun (hyunjh@hanyang.ac.kr) and Bo Thamdrup (bot@biology.sdu.dk)

Received: 23 May 2016 - Discussion started: 3 June 2016

Revised: 19 January 2017 - Accepted: 1 February 2017 - Published: 1 March 2017

\begin{abstract}
Rates and pathways of benthic organic carbon $\left(\mathrm{C}_{\text {org }}\right)$ oxidation were investigated in surface sediments of the Ulleung Basin (UB) characterized by high $\mathrm{C}_{\text {org }}$ contents $(>2.5 \%$, dry wt.) and very high contents of Mn oxides $\left(>200 \mu \mathrm{mol} \mathrm{cm}{ }^{-3}\right.$ ) and $\mathrm{Fe}$ oxides (up to $100 \mu \mathrm{mol} \mathrm{cm}{ }^{-3}$ ). The combination of geochemical analyses and independently executed metabolic rate measurements revealed that $\mathrm{Mn}$ and $\mathrm{Fe}$ reduction were the dominant $\mathrm{C}_{\text {org }}$ oxidation pathways in the center of the UB, comprising 45 and $20 \%$ of total $\mathrm{C}_{\text {org }}$ oxidation, respectively. By contrast, sulfate reduction was the dominant $\mathrm{C}_{\text {org }}$ oxidation pathway, accounting for $50 \%$ of total $\mathrm{C}_{\text {org }}$ mineralization in sediments of the continental slope. The relative significance of each $\mathrm{C}_{\text {org }}$ oxidation pathway matched the depth distribution of the respective electron acceptors. The relative importance of $\mathrm{Mn}$ reduction for $\mathrm{C}_{\mathrm{org}}$ oxidation displays saturation kinetics with respect to $\mathrm{Mn}$ oxide content with a low half-saturation value of $8.6 \mu \mathrm{mol} \mathrm{cm}{ }^{-3}$, which further implies that $\mathrm{Mn}$ reduction can be a dominant $\mathrm{C}_{\text {org }}$ oxidation process even in sediments with lower $\mathrm{MnO}_{2}$ content as known from several other locations. This is the first report of a high contribution of manganese reduction to $\mathrm{C}_{\text {org }}$ oxidation in offshore sediments on the Asian margin. The high manganese oxide content in the surface sediment in the central UB was maintained by an extreme degree of recycling, with each $\mathrm{Mn}$ atom on average being reoxidized $\sim 3800$ times before permanent burial. This is the highest
\end{abstract}

degree of recycling so far reported for Mn-rich sediments, and it appears linked to the high benthic mineralization rates resulting from the high $\mathrm{C}_{\text {org }}$ content that indicate the UB as a biogeochemical hotspot for turnover of organic matter and nutrient regeneration.

\section{Introduction}

Although they cover only $15 \%\left(47 \times 10^{6} \mathrm{~km}^{2}\right)$ of the ocean surface area, sediments of continental margins (200-2000 m depth) are characterized by enhanced organic matter flux generated either by vertical transport from the highly productive overlying water column or by lateral transport from adjacent shelves, and thus play an important role in deposition and mineralization of organic matter (Romankevich, 1984; Jahnke et al., 1990; Walsh, 1991; Jahnke and Jahnke, 2000). Organic particles that reach the seafloor are quickly mineralized by hydrolysis, fermentation, and a variety of respiratory processes using different electron acceptors such as oxygen, nitrate, Mn oxides, Fe oxides, and sulfate (Froelich et al., 1979; Jørgensen, 2006). The partitioning of organic carbon $\left(\mathrm{C}_{\mathrm{org}}\right)$ oxidation among the different electron-accepting pathways has a profound influence on the distribution and the release and/or retention of $\mathrm{Mn}, \mathrm{Fe}, \mathrm{S}$, and nutrients (nitrogen and phosphate) (Canfield et al., 2005; Hansen et al., 
2006; Jørgensen, 2006; Slomp et al., 2013). Therefore, it is particularly important to elucidate the contribution of each $\mathrm{C}_{\text {org }}$ oxidation pathway in order to better understand the role of sediments in biogeochemical element cycles.

The relative significance of each carbon oxidation pathway is largely controlled by the combination of organic matter supply and availability of electron acceptors. In general, aerobic metabolism dominates the organic matter mineralization in deep-sea sediments that are characterized by low organic matter content (Jahnke et al., 1982; Glud, 2008), especially in organic-carbon-starved deep-sea sediments with low sedimentation rates (Mewes et al., 2014, 2016; D'Hondt et al., 2015; Mogollón et al., 2016). In contrast, owing to high sulfate concentrations in marine sediment, sulfate reduction might account for up to $50 \%$ of total carbon oxidation in continental margins with high organic matter flux (Jørgensen, 1982; Jørgensen and Kasten, 2006; Bowles et al., 2014). However, in sediments where manganese and iron oxides are abundant or rapidly recycled, microbial reduction of manganese and iron can be the dominant electron-accepting processes over sulfate reduction (Sørensen and Jørgensen, 1987; Aller, 1990; Canfield et al., 1993b). The significance of dissimilatory iron reduction for $\mathrm{C}_{\text {org }}$ oxidation is well established in the sediments of various continental margins and coastal wetlands (Thamdrup, 2000; Thamdrup and Canfield, 1996; Jensen et al., 2003; Kostka et al., 2002a, b; Vandieken et al., 2006; Hyun et al., 2007, 2009b). However, only a few locations such as the Panama Basin (Aller, 1990), the coastal Norwegian trough in Skagerrak and an adjacent fjord (Canfield et al., 1993a, b; Vandieken et al., 2014), the Black Sea shelf (Thamdrup et al., 2000), and the continental shelf of the northern Barents Sea (Vandieken et al., 2006; Nickel et al., 2008) are known where microbial manganese reduction significantly contributes to carbon mineralization.

The East Sea (often referred to as Japan Sea), located in the far eastern part of the Eurasian continental margin, consists of three major basins deeper than $2000 \mathrm{~m}$, the Japan Basin, the Yamato Basin, and the Ulleung Basin (Fig. 1). Compared to the other two basins, the surface waters of the Ulleung Basin (UB) are characterized by higher phytoplankton biomass and primary production (Yamada et al., 2005; Yoo and Park, 2009), which is associated with coastal upwelling (Hyun et al., 2009a). The enhanced biological production in the euphotic zone of the UB is responsible for the high $\mathrm{C}_{\text {org }}$ content $(>2.5 \% \mathrm{wt})$ in the sediment, and the highest rates of $\mathrm{C}_{\text {org }}$ oxidation compared to other deep-sea sediments with similar depth range (Lee et al., 2008; Hyun et al., 2010). An intriguing geochemical property of the UB surface sediment is the high content of Mn oxides $\left(>200 \mu \mathrm{mol} \mathrm{cm}^{-3}\right)$ and $\mathrm{Fe}$ oxides (up to $100 \mu \mathrm{mol} \mathrm{cm} \mathrm{cm}^{-3}$ ) (Cha et al., 2007; Hyun et al., 2010). In accordance with these geochemical findings, the suppression of sulfate reduction (Hyun et al., 2010) and accumulation of $\mathrm{Mn}^{2+}$ in anoxic incubation of surface sediment (Vandieken et al., 2012) strongly implied that the $\mathrm{C}_{\text {org }}$ oxidation in the surface sediment of the UB is dominated by microbial manganese and iron reduction, but actual rates and partitioning of each electron-accepting pathway in $\mathrm{C}_{\mathrm{org}}$ oxidation remain to be determined in this deep marginal sediment underlying highly productive surface waters.

The primary objective of this paper was to characterize the sediment biogeochemistry with regard to the rate of $\mathrm{C}_{\text {org }}$ oxidation and partitioning of major terminal electron-accepting pathways at two contrasting sites at the continental slope and rise in the UB. Here, for the first time in sediments of the Asian marginal seas, we document that $\mathrm{Mn}$ reduction and $\mathrm{Fe}$ reduction are the dominant $\mathrm{C}_{\text {org }}$ oxidation pathways accounting for respectively 45 and $20 \%$ of total $\mathrm{C}_{\text {org }}$ oxidation in the center of the $\mathrm{UB}$, and suggest that $\mathrm{Mn}$ and Fe reduction may be of greater importance in deep-sea sediments than previously recognized.

\section{Materials and methods}

\subsection{Study site}

The East Sea is a marginal sea surrounded by the east Asian continent and Japanese islands (Fig. 1; Kang et al., 2010; Liu et al., 2010). The UB located in the southwestern part of the East Sea is a bowl-shaped deep basin (2000-3000 m depth) (Fig. 1) delimited by continental slopes of Korean Peninsula and the southwestern Japanese archipelago on the west and south, respectively, and by the Korea Plateau and the Oki Bank on the north and east, respectively (Chough et al., 2000).

Shipboard experiments were conducted in June 2009 at two sites on the continental slope (station M1, hereafter M1) and in the center (station D3, hereafter D3) of the UB (Fig. 1, Table 1). Surface sediments consist of fine-grained clay with a mean grain size less than $0.004 \mathrm{~mm}$ in diameter (Cha et al., 2007). Two stations were characterized by two contrasting sediment colors. The Mn oxide-enriched surface sediment at the basin site (D3) was reddish-brown, whereas at the slope site (M1) it exhibited the typical gray-brown color of muddy continental margin sediments (Fig. 1). Further environmental properties are listed in Table 1.

\subsection{Sampling and handling}

Sediment samples were collected with a box corer. Onboard, duplicate or mostly triplicate sub-samples for geochemical analyses were collected using acrylic cores $(6-9 \mathrm{~cm}$ in diameter and $30-40 \mathrm{~cm}$ in length). The sub-cores for geochemical analyses were immediately sealed with butyl rubber stoppers and transferred to a $\mathrm{N}_{2}$-filled glove bag for sectioning and loading into polypropylene centrifuge tubes that were then tightly capped and centrifuged for $15 \mathrm{~min}$ at $5000 \times \mathrm{g}$. After reintroduction into the $\mathrm{N}_{2}$-filled glove bag, pore waters were sampled and filtered through $0.2 \mu \mathrm{m}$ cellulose ester syringe filters (ADVANTEC, Toyo Rashi Kaisha, Ltd). One to $2 \mathrm{~mL}$ of pore water to determine $\mathrm{NH}_{4}^{+}$was fixed with sat- 


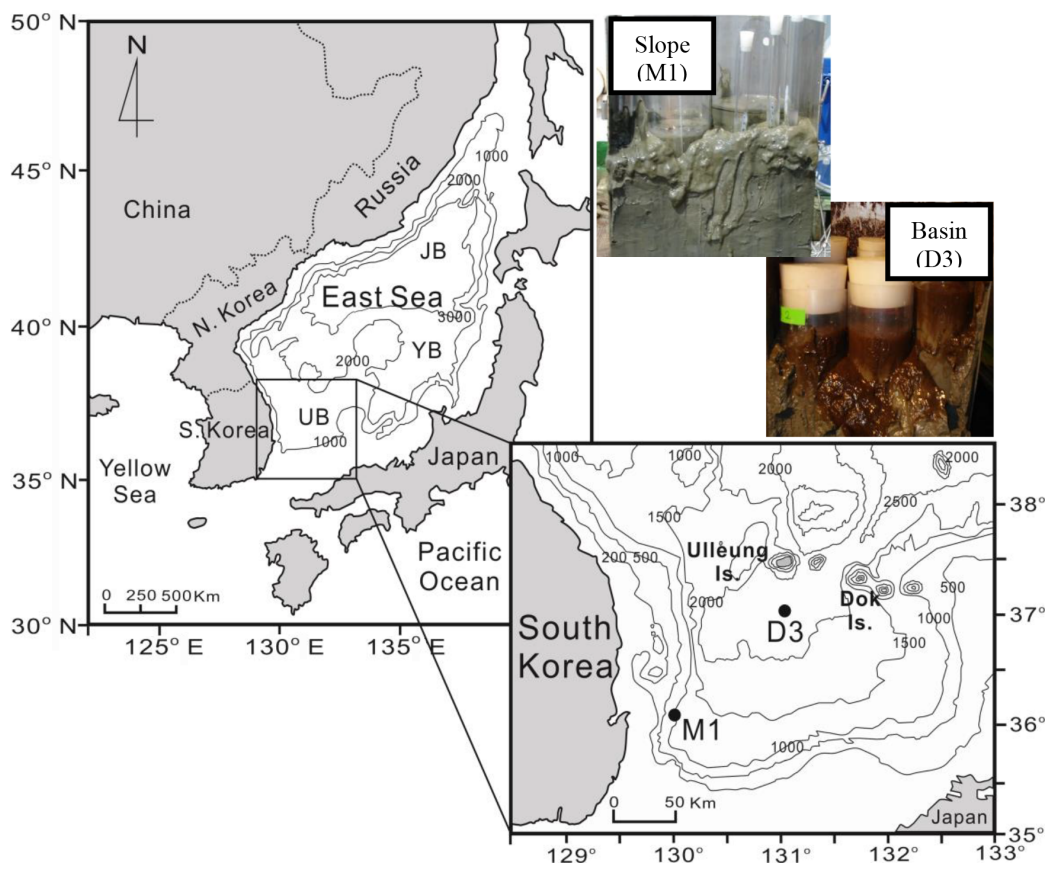

Figure 1. Sampling stations in the East Sea and pictures showing contrasting colors between surface sediments of the continental slope (M1) and center of the basin (D3).

Table 1. Environmental settings and sediment characteristics*.

\begin{tabular}{|c|c|c|}
\hline Environmental parameter & $\begin{array}{r}\text { M1 } \\
\text { (continental slope) }\end{array}$ & $\begin{array}{r}\mathrm{D} 3 \\
\text { (center of the basin) }\end{array}$ \\
\hline Latitude & $36^{\circ} 10^{\prime} \mathrm{N}$ & $37^{\circ} 00^{\prime} \mathrm{N}$ \\
\hline Longitude & $130^{\circ} 10^{\prime} \mathrm{E}$ & $131^{\circ} 00^{\prime} \mathrm{E}$ \\
\hline Water depth (m) & 1453 & 2154 \\
\hline Sediment temperature $\left({ }^{\circ} \mathrm{C}\right)$ & 1.3 & 0.6 \\
\hline Pore-water salinity (psu) & 34.2 & 34.8 \\
\hline Water content $(\%)$ & $85( \pm 3.1)$ & $77( \pm 1.8)$ \\
\hline Porosity & $0.95( \pm 0.03)$ & $0.86( \pm 0.01)$ \\
\hline Density $\left(\mathrm{g} \mathrm{cm}^{-3}\right)$ & $1.10( \pm 0.02)$ & $1.12( \pm 0.02)$ \\
\hline Total organic carbon (\%, dry wt.) & $3.96( \pm 0.27)$ & $2.66( \pm 0.09)$ \\
\hline Total nitrogen (\%, dry wt.) & $0.38( \pm 0.01)$ & $0.35( \pm 0.01)$ \\
\hline
\end{tabular}

* Numbers in parentheses indicate \pm 1 SD of triplicate samples.

urated $\mathrm{HgCl}_{2}$ and subsequently frozen. For determination of $\mathrm{Fe}^{2+}, \mathrm{Mn}, \mathrm{SO}_{4}^{2-}$ and $\mathrm{Ca}^{2+}, 2 \mathrm{~mL}$ of the pore water were acidified with $12 \mathrm{M} \mathrm{HCl}$ and stored at $4{ }^{\circ} \mathrm{C}$. Pore water for sulfide analysis was preserved with $\mathrm{Zn}$ acetate $(20 \%)$. Sediments for solid-phase analysis were frozen at $-25^{\circ} \mathrm{C}$ for future analyses.

\subsection{Anoxic bag incubations}

Anaerobic carbon mineralization rates and dissimilatory $\mathrm{Mn}$ and $\mathrm{Fe}$ reduction rates were determined in batch incubations based on the procedures of Canfield et al. (1993b) and Thamdrup and Canfield (1996). Sediment cores were transferred to a $\mathrm{N}_{2}$-filled glove bag and sliced in $2 \mathrm{~cm}$ intervals to a depth of $10 \mathrm{~cm}$. Sediment from parallel sections was pooled, mixed, and loaded into gas-tight plastic bags (Hansen et al., 2000). The bags were sealed without gas space and incubated in the dark at near in situ temperature $\left(\mathrm{ca} .1-2^{\circ} \mathrm{C}\right)$ in larger $\mathrm{N}_{2}$-filled bags to ensure anoxic conditions. Over a period of 18 days of incubation, sub-samples to determine the accumulation of total dissolved inorganic carbon (DIC) and $\mathrm{Mn}$ in pore water were withdrawn on days $0,1,3,5,9$, and 18 . Two $50 \mathrm{~mL}$ centrifuge tubes per bag were filled completely with sediment in a $\mathrm{N}_{2}$-filled glove bag, and pore water was extracted as described above. For DIC analysis, we collected $1.8 \mathrm{~mL}$ aliquots into glass vials without head space, fixed 
with $18 \mu \mathrm{L}$ of $\mathrm{HgCl}_{2}(125 \mathrm{mM})$, and stored at $4{ }^{\circ} \mathrm{C}$ until analysis within 4 weeks. Samples for Mn analysis were acidified with $12 \mathrm{M} \mathrm{HCl}$ and stored at $4{ }^{\circ} \mathrm{C}$. Sediment remaining after the collection of pore water was frozen at $-25^{\circ} \mathrm{C}$ for later analysis of oxalate-extractable solid Fe(II).

\subsection{Pore-water analyses}

Total dissolved inorganic carbon (DIC) and $\mathrm{NH}_{4}^{+}$were measured by flow injection analysis with conductivity detection (Hall and Aller, 1992). Nitrate was measured spectrophotometrically (Parsons et al., 1984). Dissolved $\mathrm{Fe}^{2+}$ was determined by colorimetric method with ferrozine (Stookey, 1970). Dissolved $\mathrm{Mn}^{2+}$ and $\mathrm{Ca}^{2+}$ were analyzed in acidified pore water by inductively coupled plasmaatomic emission spectrometry (ICP-AES, Optima 3300DV, PerkinElmer Co.) and flame atomic absorption spectrometer (SpectrAA 220/FS, Varian), respectively (Thamdrup and Canfield, 1996). Dissolved sulfide was determined by the methylene blue method (Cline, 1969). Sulfate concentrations were measured using ion chromatography (Metrohm 761). The detection limit of $\mathrm{H}_{2} \mathrm{~S}, \mathrm{Ca}^{2+}, \mathrm{Mn}^{2+}$, and $\mathrm{Fe}^{2+}$ was 3, $1.8,3$, and $1 \mu \mathrm{M}$, respectively. Reproducibility of DIC and $\mathrm{NH}_{4}^{+}$was better than $10 \%$. Precision of $\mathrm{NO}_{3}^{-}$was $1-2 \%$.

\subsection{Solid-phase analyses}

Total oxalate-extractable Fe [Fe(II) + Fe(III)] was extracted from air-dried sediment in a $0.2 \mathrm{M}$ oxic oxalate solution (pH 3) for $4 \mathrm{~h}$ (Thamdrup and Canfield, 1996), and Fe(II) was extracted from frozen sediment in anoxic oxalate (Phillips and Lovley, 1987). The total oxalate-extractable Fe and $\mathrm{Fe}(\mathrm{II})$, hereafter total $\mathrm{Fe}_{(\text {oxal }}$ and $\mathrm{Fe}$ (II)(oxal), were determined as described for the pore-water analysis of $\mathrm{Fe}^{2+}$. Oxalate-extractable $\mathrm{Fe}(\mathrm{III})$, hereafter $\mathrm{Fe}(\mathrm{III})_{(\mathrm{oxal})}$, was defined as the difference between total $\mathrm{Fe}_{\text {(oxal) }}$ and $\mathrm{Fe}$ (II)(oxal). This fraction represents poorly crystalline $\mathrm{Fe}(\mathrm{III})$ oxides. Particulate $\mathrm{Mn}$, hereafter $\mathrm{Mn}_{(\mathrm{DCA})}$ was extracted with dithionite-citrate-acetic acid (DCA; pH 4.8) for $4 \mathrm{~h}$ from air-dried sediment and was determined by inductively coupled plasma-atomic emission spectrometry (ICP-AES, Optima 3300DV, PerkinElmer Co). The DCA extraction aims at dissolving free $\mathrm{Mn}$ oxides and authigenic $\mathrm{Mn}(\mathrm{II})$ phases. The reproducibility of the measurements was better than $10 \%$ and the detection limits were $3 \mu \mathrm{M}$ for $\mathrm{Mn}$ and $1 \mu \mathrm{M}$ for Fe. For the determination of total reduced sulfur (TRS) that includes acid-volatile sulfide $\left(\mathrm{AVS}=\mathrm{FeS}+\mathrm{H}_{2} \mathrm{~S}\right.$ and small amounts of other metal sulfides; see Rickard and Morse, 2005; Luther III, 2005) and chromium-reducible sulfur $\left(C R S=S^{0}+F_{2} S_{2}\right)$, sediment samples were fixed with $\mathrm{Zn}$ acetate, and sulfide was determined according to the method of Cline (1969) after a two-step distillation with cold $12 \mathrm{M} \mathrm{HCl}$ and boiling $0.5 \mathrm{M} \mathrm{Cr}^{2+}$ solution (Fossing and Jørgensen, 1989). The contents of total organic carbon (TOC) and nitrogen (TN) in the surface sediment were analyzed us- ing a CHN analyzer (CE Instruments, EA 1110) after removing $\mathrm{CaCO}_{3}$ using $12 \mathrm{M} \mathrm{HCl}$.

\subsection{Oxygen micro-profiles}

Oxygen profiles were measured at $50 \mu \mathrm{m}$ resolution using Clark-type microelectrodes (Unisense, OX-50) while stirring the overlying water. Microelectrodes were calibrated between $100 \%$ air-saturated in situ bottom water and $\mathrm{N}_{2}$ purged anoxic bottom water. Three profiles were measured at each site. The diffusive boundary layer (DBL) and sediment-water interface (SWI) were determined according to Jørgensen and Revsbech (1985). To estimate the volumespecific oxygen consumption rate, we used the PROFILE software (Berg et al., 1998).

\subsection{Rate measurements}

The diffusive oxygen uptake (DOU) was calculated from the calibrated oxygen micro-profiles.

$\mathrm{DOU}=-D_{o} \times(\Delta C / \Delta z)$,

where $D_{o}\left(1.07 \times 10^{-9} \mathrm{~m}^{2} \mathrm{~s}^{-1}\right.$ at M1 and $1.03 \times 10^{-9} \mathrm{~m}^{2} \mathrm{~s}^{-1}$ at D3) is the temperature-corrected molecular diffusion coefficient estimated from Schulz (2006), and $C$ is the oxygen concentration at depth $z$ within the diffusive boundary layer (DBL) (Jørgensen and Revsbech, 1985).

The volume-specific $\mathrm{O}_{2}$ consumption rates exhibited a bimodal depth distribution (see Sect. 3.2) with activity peaks near the SWI and the oxic-anoxic interface, respectively. Thus, $\mathrm{O}_{2}$ consumption rates by aerobic organotrophic respiration were defined as the $\mathrm{O}_{2}$ consumption rate near the SWI, whereas the oxygen consumption at the oxic-anoxic interface was assigned to re-oxidation of reduced inorganic compounds (Rasmussen and Jørgensen, 1992; Canfield et al., 2005).

Total anaerobic $\mathrm{C}_{\text {org }}$ mineralization rates were determined by linear regression of the accumulation of total DIC with time during the anoxic bag incubations (Fig. 3) after correcting for $\mathrm{CaCO}_{3}$ precipitation (Thamdrup et al., 2000). Briefly, $\mathrm{CaCO}_{3}$ precipitation was calculated from decreasing dissolved $\mathrm{Ca}^{2+}$ concentration during the anoxic bag incubation:

$\Delta \mathrm{CaCO}_{3}=\Delta\left[\mathrm{Ca}^{2+}\right]_{\mathrm{sol}} \times\left(1+K_{\mathrm{Ca}}\right)$,

where $K_{\mathrm{Ca}}$ is the adsorption constant for $\mathrm{Ca}^{2+}\left(K_{\mathrm{Ca}}=1.6\right)$ ( $\mathrm{Li}$ and Gregory, 1974). Then the DIC production rate corrected for $\mathrm{CaCO}_{3}$ precipitation was calculated as

DIC production $=$ DIC accumulation

$$
+\mathrm{CaCO}_{3} \text { precipitation. }
$$

$\mathrm{Fe}(\mathrm{III})$ reduction rates were determined by linear regression of the increase in solid-phase $\mathrm{Fe}(\mathrm{II})_{(\text {oxal }}$ content with time during anoxic bag incubations. The dissimilatory microbial 
$\mathrm{Fe}(\mathrm{III})$ reduction rate was derived by subtracting abiotic $\mathrm{Fe}$ reduction coupled to the oxidation of sulfide produced by sulfate reduction (Gribsholt et al., 2003):

$$
\begin{aligned}
& \text { Dissimilatory microbial Fe(III) red. } \\
& \quad=\text { total Fe(III) red. - abiotic Fe(III) red., }
\end{aligned}
$$

assuming that abiotic $\mathrm{Fe}$ reduction coupled to $\mathrm{H}_{2} \mathrm{~S}$ oxidation occurred at a stoichiometry of $2 \mathrm{Fe}(\mathrm{III})$ per $3 \mathrm{H}_{2} \mathrm{~S}$ (Pyzik and Sommer, 1981; Melton et al., 2014):

$2 \mathrm{FeOOH}+3 \mathrm{H}_{2} \mathrm{~S}_{\text {(produced by } \mathrm{SR})}=2 \mathrm{FeS}+\mathrm{S}^{0}+4 \mathrm{H}_{2} \mathrm{O}$.

Finally, to estimate the $\mathrm{C}_{\text {org }}$ oxidation by microbial Fe reduction, the $4: 1$ stoichiometry of iron reduction coupled to $\mathrm{C}_{\mathrm{org}}$ oxidation was used from the stoichiometric equation (Canfield et al., 1993a):

$\mathrm{CH}_{2} \mathrm{O}+4 \mathrm{FeOOH}+8 \mathrm{H}^{+}=\mathrm{CO}_{2}+4 \mathrm{Fe}^{2+}+7 \mathrm{H}_{2} \mathrm{O}$.

Mn reduction rates were determined from linear regression of the production of dissolved $\mathrm{Mn}^{2+}$ with time during the anoxic bag incubations. Similar to previous studies (e.g., Canfield et al., 1993a, b; Thamdrup and Dalsgaard, 2000), we assumed that accumulating dissolved $\mathrm{Mn}$ was $\mathrm{Mn}^{2+}$. This ignores a potential contribution from $\mathrm{Mn}^{3+}$, which in some cases can constitute a substantial fraction of the dissolved $\mathrm{Mn}$ pool at the upper boundary of the zone with soluble Mn accumulation in marine sediments (Madison et al., 2013). Further studies of the dynamics of soluble $\mathrm{Mn}^{3+}$ are required to evaluate its potential importance in anoxic incubations. Such studies pending, we find justification for our assumption in the good agreement observed in the previous studies between $\mathrm{Mn}$ reduction rates calculated based on the assumption that soluble $\mathrm{Mn}$ is $\mathrm{Mn}^{2+}$ (Eq. 7) and independent estimates of rates of carbon mineralization through dissimilatory $\mathrm{Mn}$ reduction based on DIC or $\mathrm{NH}_{4}^{+}$accumulation. Due to strong adsorption of $\mathrm{Mn}^{2+}$ to $\mathrm{Mn}$ oxide surfaces (Canfield et al., 1993b), the Mn reduction rates were estimated after compensating for the adsorption effect of $\mathrm{Mn}^{2+}$ to $\mathrm{Mn}$ oxides according to Thamdrup and Dalsgaard (2000):

$$
\begin{aligned}
& \text { Mn reduction rate } \\
& \quad=\mathrm{Mn}^{2+} \text { accumulation rate } \\
& \quad \times\left(1+K^{*}{ }_{\mathrm{Mn}^{2+}} \times(1-\Phi) \times \Phi^{-1} \times \delta_{\mathrm{s}}\right),
\end{aligned}
$$

where $\Phi$ is porosity, $\delta_{\mathrm{s}}$ is density of sediment, $K^{*}{ }_{\mathrm{Mn}^{2+}}=$ $4.8+0.14 \times[\mathrm{Mn}(\mathrm{IV})]\left(\mathrm{mL} \mathrm{g}^{-1}\right)$, and $[\mathrm{Mn}(\mathrm{IV})]$ is the content of $\mathrm{Mn}(\mathrm{IV})\left(\mu \mathrm{mol} \mathrm{g}^{-1}\right)$.

We here assume that extracted $\mathrm{Mn}_{(\mathrm{DCA})}$ represents $\mathrm{Mn}(\mathrm{IV})$ as observed in surface sediments of another Mn-rich site (Canfield et al., 1993b; Thamdrup and Dalsgaard, 2000). Small levels of $\mathrm{Mn}_{(\mathrm{DCA})}$ remaining at depth further suggest that little Mn(II) accumulates in the solid phase (see Results). $\mathrm{C}_{\text {org }}$ oxidation by dissimilatory $\mathrm{Mn}(\mathrm{IV})$ reduction was calculated from the stoichiometric equation (Canfield et al., 1993a):

$$
\mathrm{CH}_{2} \mathrm{O}+2 \mathrm{MnO}_{2}+4 \mathrm{H}^{+}=\mathrm{CO}_{2}+2 \mathrm{Mn}^{2+}+3 \mathrm{H}_{2} \mathrm{O} \text {. }
$$

Sulfate reduction rates were determined using the radiotracer method of Jørgensen (1978). Sediment cores ( $35 \mathrm{~cm}$ long with $2.9 \mathrm{~cm}$ i.d.) were collected in triplicate, injected horizontally at $1 \mathrm{~cm}$ vertical interval with $5 \mu \mathrm{L}$ radiolabeled sulfate $\left({ }^{35} \mathrm{~S}_{-} \mathrm{SO}_{4}^{2-}, 15 \mathrm{kBq} \mu \mathrm{L}^{-1}\right.$, Amersham), diluted in sterilized $\mathrm{NaCl}$ solution $(3.0 \%)$, and incubated for $12 \mathrm{~h}$ at in situ temperature. At the end of the incubation, the sediment was sliced into sections, fixed in $\mathrm{Zn}$ acetate $(20 \%)$, and frozen at $-25{ }^{\circ} \mathrm{C}$ until processed in the laboratory. The reduced ${ }^{35} \mathrm{~S}$ was recovered using distillation with a boiling acidic $\mathrm{Cr}^{2+}$ solution according to Fossing and Jørgensen (1989). Background radioactivity of ${ }^{35} \mathrm{~S}$ was $32.4 \pm 3.7 \mathrm{cpm} \mathrm{cm}^{-3}(n=$ $10)$ at site $\mathrm{D} 3$ and $87.5 \pm 38.7 \mathrm{cpm} \mathrm{cm}^{-3}(n=10)$ at site M1. Detection limits of the sulfate reduction rate (SRR), estimated from the double standard deviation of the blank value (i.e., 7.4 and $77.4 \mathrm{cpm}$ ) according to Fossing et al. (2000), ranged from 0.79 to $2.62 \mathrm{nmol} \mathrm{cm}^{-3} \mathrm{~d}^{-1}$. To elucidate the contribution of sulfate reduction in anaerobic carbon oxidation, the SRRs (Fig. 5b, g) were converted to carbon oxidation using a stoichiometric equation (Thamdrup and Canfield, 1996):

$$
2 \mathrm{CH}_{2} \mathrm{O}+\mathrm{SO}_{4}^{2-}+2 \mathrm{H}^{+}=2 \mathrm{CO}_{2}+\mathrm{H}_{2} \mathrm{~S}+2 \mathrm{H}_{2} \mathrm{O} .
$$

\section{Results}

\subsection{Pore-water and solid-phase constituents}

The depth distributions of $\mathrm{NH}_{4}^{+}, \mathrm{NO}_{3}^{-}, \mathrm{Mn}^{2+}$, and $\mathrm{Fe}^{2+}$ in the pore water as well as solid-phase $\mathrm{Mn}, \mathrm{Fe}$, and $\mathrm{S}$ for the two stations are shown in Fig. 2. $\mathrm{NH}_{4}^{+}$concentrations at M1 increased steadily with depth (Fig. 2a), whereas at D3 it decreased down to $3 \mathrm{~cm}$ depth before it increased below (Fig. 2f). Highest concentrations of nitrate were measured at 0 to $1 \mathrm{~cm}$ sediment depth at the two stations and concentrations decreased below a background level $(<2 \mu \mathrm{M})$ below $1 \mathrm{~cm}$ at both M1 and D3 (Fig. 2a, f). Dissolved $\mathrm{Mn}^{2+}$ concentrations differed widely between the sites showing a maximum of $56 \mu \mathrm{M}$ between 0 and $3 \mathrm{~cm}$ depth and not exceeding $10 \mu \mathrm{M}$ below at M1 (Fig. 2b), whereas at D3 concentrations increased to a maximum of $286 \mu \mathrm{M}$ at $10-12 \mathrm{~cm}$ depth (Fig. 2g). Conversely, dissolved $\mathrm{Fe}^{2+}$ concentrations at M1 increased from $11 \mu \mathrm{M}$ at $0-0.5 \mathrm{~cm}$ to $32 \mu \mathrm{M}$ at $6-7 \mathrm{~cm}$ depth, and stayed constant below (Fig. 2c), whereas at D3, concentrations were uniformly low, showing a slight increase to $12 \mu \mathrm{M}$ at $15 \mathrm{~cm}$ (Fig. $2 \mathrm{~h}$ ).

Extractable $\mathrm{Mn}\left(\mathrm{Mn}_{(\mathrm{DCA})}\right)$ contents were low $\left(<3 \mu \mathrm{mol} \mathrm{cm}{ }^{-3}\right)$ in the upper $20 \mathrm{~cm}$ at the slope site (M1) (Fig. 2b), but up to $200 \mu \mathrm{mol} \mathrm{cm}{ }^{-3}$ in the upper $4 \mathrm{~cm}$ depth of the sediment at the center of the basin (D3), 

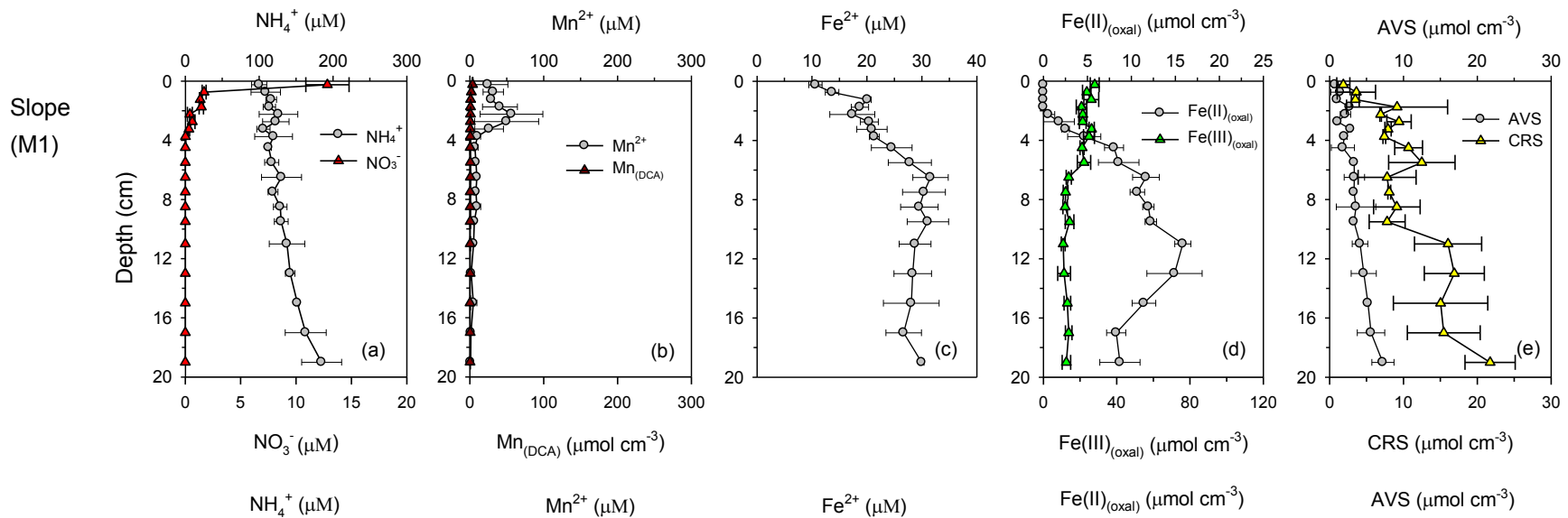

Basin
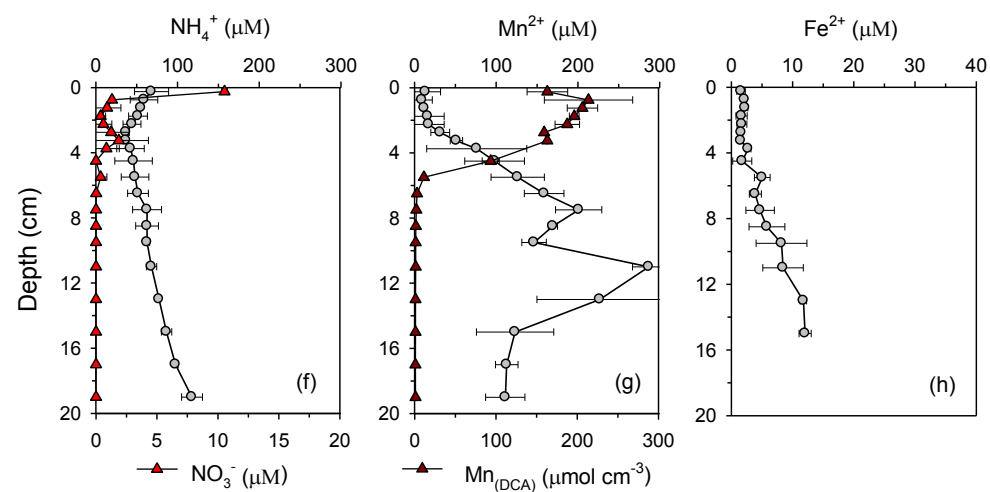

$\mathrm{Fe}(\mathrm{II})_{\text {(oxal) }}\left(\mu \mathrm{mol} \mathrm{cm} \mathrm{cm}^{-3}\right)$

AVS $\left(\mu \mathrm{mol} \mathrm{cm}{ }^{-3}\right)$

(D3)

Figure 2. Concentrations of dissolved $\mathrm{NH}_{4}^{+}, \mathrm{NO}_{3}^{-}, \mathrm{Mn}^{2+}$, and $\mathrm{Fe}^{2+}$ in pore water and contents of solid-phase $\mathrm{Mn}(\mathrm{DCA}), \mathrm{Fe}(\mathrm{II})(\mathrm{oxal})$, $\mathrm{Fe}(\mathrm{III})_{(\text {oxal) }}$, acid-volatile sulfur (AVS), and chromium-reducible sulfur (CRS) in the sediment at M1 and D3.

Table 2. Oxygen penetration depth (OPD), diffusive oxygen utilization (DOU) rate and $\mathrm{O}_{2}$ consumption rate by aerobic respiration and re-oxidation of reduced inorganic compounds (RIC) in the pore water. Values represent averages $\pm 1 \mathrm{SD}(n=3)$.

\begin{tabular}{lrrrr}
\hline Station & OPD & DOU & \multicolumn{2}{c}{$\mathrm{O}_{2}$ consumption $\left(\mathrm{mmol} \mathrm{O}_{2} \mathrm{~m}^{-2} \mathrm{~d}^{-1}\right)$ by } \\
\cline { 4 - 5 } & $(\mathrm{mm})$ & $\left(\mathrm{mmol} \mathrm{O}_{2} \mathrm{~m}^{-2} \mathrm{~d}^{-1}\right)$ & Aerobic respiration & Re-oxidation of RIC \\
\hline M1 & $3.2( \pm 0.20)$ & $7.12( \pm 1.36)$ & $4.04( \pm 2.03)$ & $3.07( \pm 0.68)$ \\
D3 & $3.6( \pm 0.03)$ & $5.95( \pm 0.16)$ & $2.53( \pm 0.72)$ & $3.42( \pm 0.58)$ \\
\hline
\end{tabular}

with a sharp decrease to near depletion $\left(\sim 1 \mu \mathrm{mol} \mathrm{cm}{ }^{-3}\right)$ below $10 \mathrm{~cm}$ (Fig. 2g). At the slope site (M1), contents of $\mathrm{Fe}(\mathrm{III})_{\text {(oxal) }}$ decreased slightly with increasing depth from $28 \mu \mathrm{mol} \mathrm{cm}{ }^{-3}$ near the surface to $13 \mu \mathrm{mol} \mathrm{cm}{ }^{-3}$ at $20 \mathrm{~cm}$ depth, mirroring an increase in Fe(II)(oxal) (Fig. 2d). At the center of the basin (D3), Fe(III) (oxal) increased slightly from $67 \mu \mathrm{mol} \mathrm{cm}{ }^{-3}$ at $0-0.5 \mathrm{~cm}$ to $90 \mu \mathrm{mol} \mathrm{cm} \mathrm{cm}^{-3}$ at $4-6 \mathrm{~cm}$ depth, and it decreased steeply below to $4.8 \mu \mathrm{mol} \mathrm{cm} \mathrm{cm}^{-3}$ at $12-14 \mathrm{~cm}$ depth (Fig. 2i). Of total $\mathrm{Fe}_{(\text {oxal) }}, \mathrm{Fe}$ (III)(oxal) comprised $>98 \%$ at $0-2 \mathrm{~cm}$ and $>97 \%$ at $0-8 \mathrm{~cm}$ depth at M1 and D3, respectively. The fraction of $\mathrm{Fe}(\mathrm{III})_{(\text {oxal }}$ in $\mathrm{Fe}_{\text {(oxal) }}$ then decreased to $40 \%$ at $10-12 \mathrm{~cm}$ depth at both sites. Acid-volatile sulfur (AVS) exhibited a slight increase with depth at $\mathrm{M} 1$ from $0.8 \mu \mathrm{mol} \mathrm{cm}{ }^{-3}$ at the surface to $7.2 \mu \mathrm{mol} \mathrm{cm}^{-3}$ at $20 \mathrm{~cm}$ depth (Fig. 2e) but was not detected at D3 (Fig. 2j). Chromium-reducible sulfur (CRS) contents at M1 increased rapidly with depth from $1.9 \mu \mathrm{mol} \mathrm{cm} \mathrm{cm}^{-3}$ at $0-0.5 \mathrm{~cm}$ to $21.8 \mu \mathrm{mol} \mathrm{cm} \mathrm{cm}^{-3}$ at $20 \mathrm{~cm}$ depth (Fig. 2e), whereas the CRS contents remained $<0.1 \mu \mathrm{mol} \mathrm{cm}{ }^{-3}$ at D3 (Fig. 2j).

\section{2 $\mathrm{O}_{2}$ micro-profiles and diffusive oxygen uptake rate}

Oxygen penetrated less than $4 \mathrm{~mm}$ into the sediments (Fig. 3), and rates of diffusive oxygen uptake (DOU) were 7.1 and $6.0 \mathrm{mmol} \mathrm{O}_{2} \mathrm{~m}^{-2} \mathrm{~d}^{-1}$ at M1 and D3, respectively (Table 2). Oxygen consumption by aerobic respiration estimated from the $\mathrm{O}_{2}$ micro-profiles (area I and II in Fig. 3) was higher at the $\mathrm{M} 1$ in the slope site $\left(4.0 \mathrm{mmol} \mathrm{O}_{2} \mathrm{~m}^{-2} \mathrm{~d}^{-1}\right)$ than at the $\mathrm{D} 3$ in the center of the basin $\left(2.5 \mathrm{mmol} \mathrm{O}_{2} \mathrm{~m}^{-2} \mathrm{~d}^{-1}\right) . \mathrm{O}_{2}$ consumption by re-oxidation of reduced inorganic compounds indicated by increased activity at the oxic-anoxic interface 

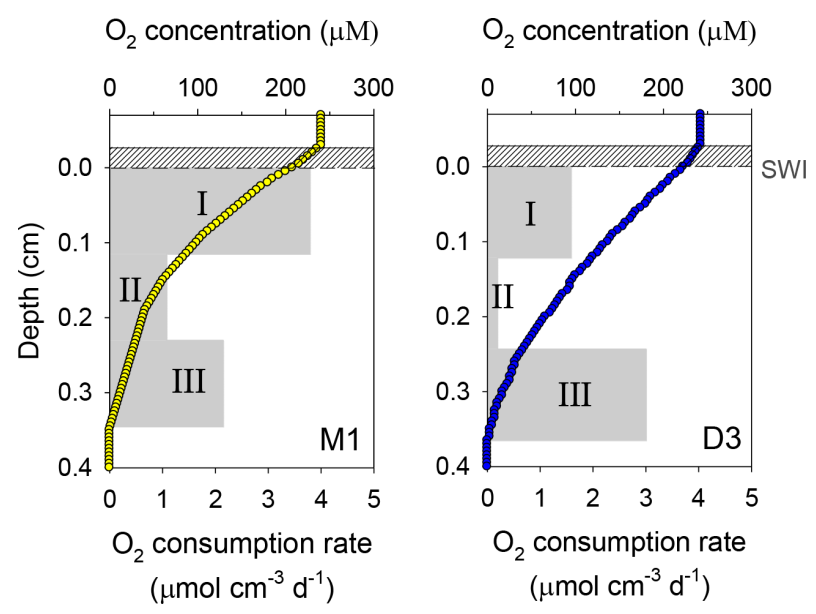

Figure 3. Vertical profiles of $\mathrm{O}_{2}$. The slashed area indicates the diffusive boundary layer in the sediment-water interface (SWI). The shaded areas indicate $\mathrm{O}_{2}$ consumption by aerobic respiration (I and II) and re-oxidation of reduced inorganic compounds (III).

(area III in Fig. 3) accounted for 43 and $57 \%$ of the DOU at M1 and D3, respectively. From the profiles of geochemical constituents (Fig. 2), $\mathrm{O}_{2}$ consumption was mainly attributed to the re-oxidation of sulfide and $\mathrm{Fe}^{2+}$ at $\mathrm{M} 1$ and of $\mathrm{Mn}^{2+}$ at D3.

\subsection{Anoxic bag incubations}

Changes in concentrations of DIC, $\mathrm{Ca}^{2+}$, and dissolved $\mathrm{Mn}^{2+}$ and solid $\mathrm{Fe}(\mathrm{II})_{(\mathrm{oxal})}$ contents over time during anoxic bag incubations from sediment of $0-2,2-4,4-6$, and $6-8 \mathrm{~cm}$ depth intervals are presented in Fig. 4. The DIC concentrations increased linearly over time during incubations of sediment in all bags from M1 and D3, except the bag from $6-8 \mathrm{~cm}$ at D3. The DIC accumulation rates were generally higher at the slope site (M1) than at the basin site (D3) (Table 4). The concentrations of $\mathrm{Ca}^{2+}$ decreased with time at all depth intervals of $\mathrm{M} 1$, whereas a decrease in $\mathrm{Ca}^{2+}$ was observed only for the $2-4 \mathrm{~cm}$ depth interval at D3. The decrease in $\mathrm{Ca}^{2+}$ indicates $\mathrm{CaCO}_{3}$ precipitation, which consequently underestimates DIC accumulation, especially at M1.

Coinciding with high solid $\mathrm{Mn}_{(\mathrm{DCA})}$ contents (Fig. $2 \mathrm{~g}$ ), prominent $\mathrm{Mn}^{2+}$ accumulation appeared at $0-6 \mathrm{~cm}$ depth of D3, whereas no increase in $\mathrm{Mn}^{2+}$ was observed at M1 except a slight accumulation at $0-2 \mathrm{~cm}$ interval (Fig. 4). Solid $\mathrm{Fe}(\mathrm{III})_{\text {(oxal) }}$ contents increased linearly with time at $0-4 \mathrm{~cm}$ depth of M1, whereas highest Fe(II) (oxal) accumulation was observed at 4-6 cm depth at D3. An increase in Fe(II)(oxal) was not discernible in the Mn oxide-rich surface sediment $(0-2 \mathrm{~cm})$ of D3.

\subsection{Sulfate reduction rates (SRRs)}

At the slope site (M1), SRR increased from $18 \mathrm{nmol} \mathrm{cm}^{-3} \mathrm{~d}^{-1}$ at the surface to $97-103 \mathrm{nmol} \mathrm{cm}^{-3} \mathrm{~d}^{-1}$ at
$1.5-2 \mathrm{~cm}$ depth, and decreased below to $12.5 \mathrm{nmol} \mathrm{cm}{ }^{-3} \mathrm{~d}^{-1}$ at $20 \mathrm{~cm}$ depth (Fig. 5b). In contrast, SRR at the manganese oxide-rich basin site (D3) ranged from 1.7 to $8.7 \mathrm{nmol} \mathrm{cm}^{-3} \mathrm{~d}^{-1}$, and did not vary with depth (Fig. $5 \mathrm{~g}$ ). Depth-integrated SRR down to $10 \mathrm{~cm}$ depth was 10 times higher at M1 $\left(4.3 \mathrm{mmol} \mathrm{m}^{-2} \mathrm{~d}^{-1}\right)$ than at D3 $\left(0.4 \mathrm{mmol} \mathrm{m}^{-2} \mathrm{~d}^{-1}\right)$ (Table 3).

\subsection{DIC production rates}

Vertical profiles of the DIC production rate that were derived from the linear regression of the DIC production measured in anoxic bag incubation (Fig. 4) after correcting for $\mathrm{CaCO}_{3}$ precipitation are presented in Fig. $5 \mathrm{c}$ and $\mathrm{h}$ for M1 and D3, respectively. At M1, the DIC production rates decreased with depth from $280 \mathrm{nmol} \mathrm{cm}{ }^{-3} \mathrm{~d}^{-1}(0-2 \mathrm{~cm}$ depth) to $69 \mathrm{nmol} \mathrm{cm}^{-3} \mathrm{~d}^{-1}$ (8-10 $\mathrm{cm}$ depth) (Fig. $5 \mathrm{c}$ ), whereas the DIC production rates at D3 were relatively similar across the upper $6 \mathrm{~cm}$ ranging from 86 to $136 \mathrm{nmol} \mathrm{cm}^{-3} \mathrm{~d}^{-1}$, and decreased to $8-15 \mathrm{nmol} \mathrm{cm}^{-3} \mathrm{~d}^{-1}$ at $6-10 \mathrm{~cm}$ (Fig. 5h). The integrated DIC production rate within $10 \mathrm{~cm}$ depth of the sediment was twice as high at $\mathrm{M} 1\left(14.0 \mathrm{mmol} \mathrm{m}^{-2} \mathrm{~d}^{-1}\right)$ as at the D3 (7.2 $\left.\mathrm{mmol} \mathrm{m}^{-2} \mathrm{~d}^{-1}\right)$ (Table 4).

\subsection{Rates of $\mathrm{Mn}$ and $\mathrm{Fe}$ reduction}

The accumulation of $\mathrm{Mn}^{2+}$ presented evidence that manganese reduction was occurring in the surface sediment $(0$ $6 \mathrm{~cm}$ ) of D3 (Fig. 4). The manganese reduction rate (MnRR) derived from $\mathrm{Mn}^{2+}$ accumulation with correction for adsorption ranged from $7.5 \mathrm{nmol} \mathrm{cm}{ }^{-3} \mathrm{~d}^{-1}(0-2 \mathrm{~cm}$ depth) to $198 \mathrm{nmol} \mathrm{cm}^{-3} \mathrm{~d}^{-1}$ (2-4 cm depth) at D3 (Fig. 5i). In contrast, MnRR at M1 was indiscernible except for low activity $\left(2.2 \mathrm{nmol} \mathrm{cm}^{-3} \mathrm{~d}^{-1}\right)$ at $0-2 \mathrm{~cm}$ depth (Fig. $5 \mathrm{~d}$ ). Depthintegrated MnRR at D3 $\left(8.21 \mathrm{mmol} \mathrm{m}^{-2} \mathrm{~d}^{-1}\right)$ was 200 times higher than the MnRR at M1 $\left(0.04 \mathrm{mmol} \mathrm{m}^{-2} \mathrm{~d}^{-1}\right)$ (Table 3). The iron reduction rate (FeRR), derived from $\mathrm{Fe}(\mathrm{II})_{(\text {oxal }}$ accumulation, at M1 was highest in the $0-2 \mathrm{~cm}$ interval $\left(237 \mathrm{nmol} \mathrm{cm}^{-3} \mathrm{~d}^{-1}\right)$, and then decreased with depth to $38 \mathrm{nmol} \mathrm{cm}^{-3} \mathrm{~d}^{-1}$ at $8-10 \mathrm{~cm}$ depth (Fig. 5e). In contrast, Fe reduction was not detected in the surface sediment at D3, but increased to its maximum rate of $240 \mathrm{nmol} \mathrm{cm}^{-3} \mathrm{~d}^{-1}$ at $4-6 \mathrm{~cm}$ depth. The FeRR then decreased with depth to $12 \mathrm{nmol} \mathrm{cm}^{-3} \mathrm{~d}^{-1}$ at $8-10 \mathrm{~cm}$ (Fig. $5 \mathrm{j}$ ), where a few data points were adopted to derive the line of best-fit regression. Depth-integrated total FeRR was slightly higher at M1 $\left(11.4 \mathrm{mmol} \mathrm{m}^{-2} \mathrm{~d}^{-1}\right)$ than at D3 $\left(7.53 \mathrm{mmol} \mathrm{m}^{-2} \mathrm{~d}^{-1}\right)(\mathrm{Ta}-$ ble 3). The ratio of microbial Fe reduction, Fe red.(microbial), to abiotic $\mathrm{Fe}$ reduction coupled to sulfide oxidation, $\mathrm{Fe}$ red.(abiotic), ranged from $1.14(8-10 \mathrm{~cm}$ at M1) to 52.3 (2$4 \mathrm{~cm}$ at D3), which indicated that the Fe reduction at $\mathrm{Mn}$ and $\mathrm{Fe}$ oxide-rich basin site was mostly a microbiologically mediated process (Table 3 ). 
Depth interval

$(\mathrm{cm})$

$(0-2)$
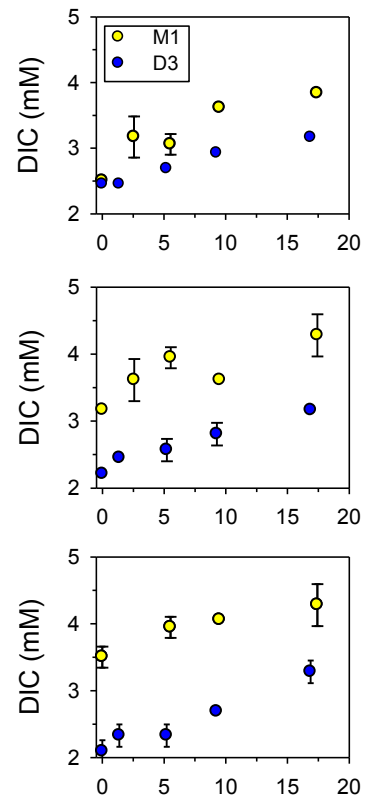

(6-8)

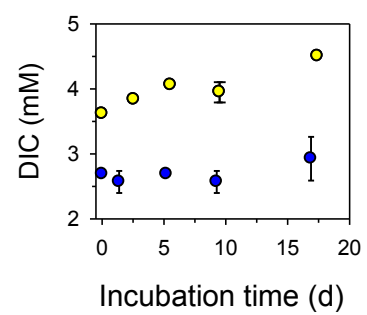

$\mathrm{Ca}^{2+}$
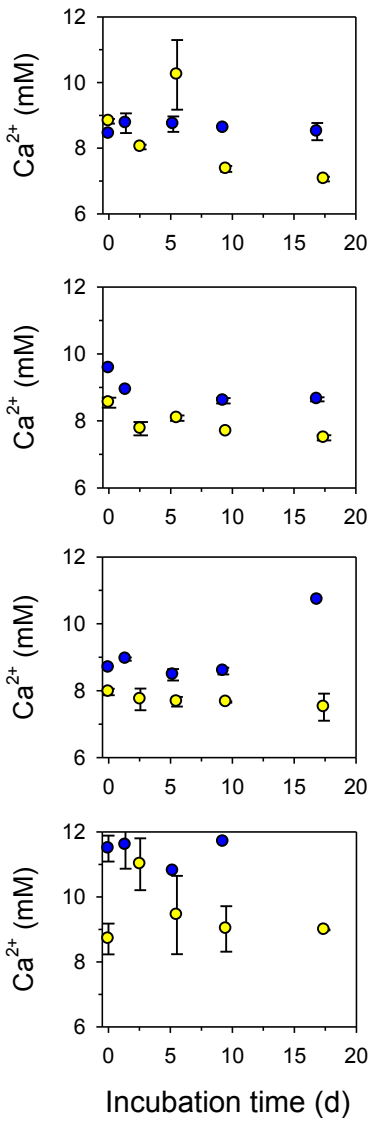

$\mathrm{Mn}^{2+}$
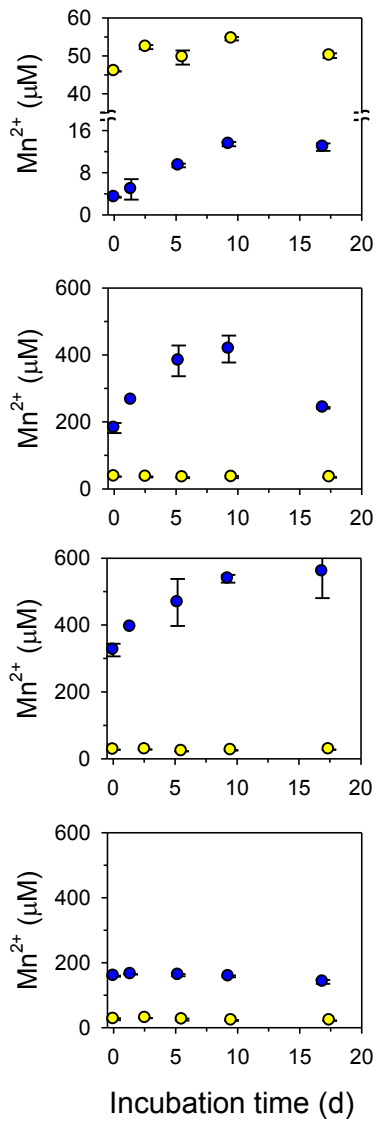

$\mathrm{Fe}(\mathrm{II})_{(\mathrm{oxal})}$
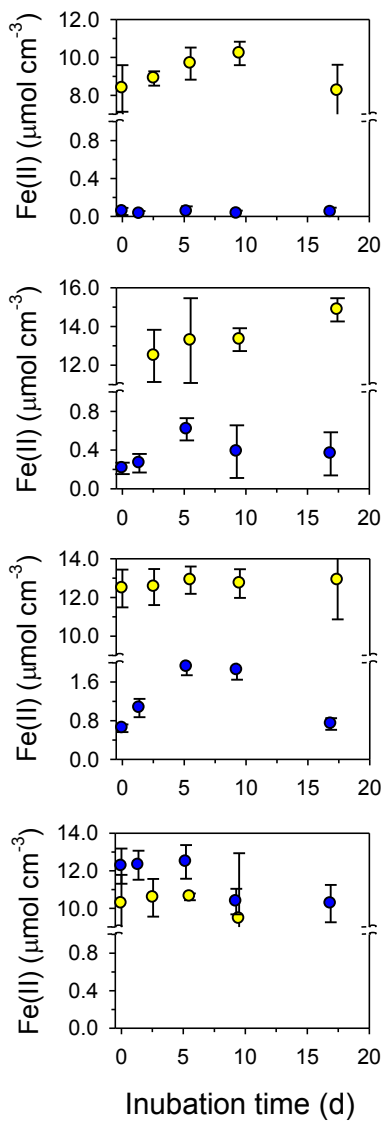

Figure 4. Changes of concentrations of DIC, $\mathrm{Ca}^{2+}$, and $\mathrm{Mn}^{2+}$ in pore water and contents of solid-phase $\mathrm{Fe}(\mathrm{II})_{(\mathrm{oxal})}$ during anoxic bag incubations of sediments from 0-2, 2-4, 4-6, and 6-8 cm depth at M1 and D3. Data obtained at the 8-10 cm depth interval are not shown.

\section{Discussion}

\subsection{Partitioning of $\mathrm{C}_{\text {org }}$ oxidation in accordance with the distribution of terminal electron acceptors}

One of the most prominent features revealed from the vertical distributions of geochemical constituents at the basin site (D3) was that electron acceptors such as $\mathrm{O}_{2}$, nitrate, and $\mathrm{Mn}$ and $\mathrm{Fe}$ oxides were systematically distributed with discrete zonation according to the order of decreasing energy yield for $\mathrm{C}_{\text {org }}$ oxidation (Fig. 5f). Such biogeochemical zones are not sharply separated in most aquatic sediments due to, for example, sediment heterogeneity and mixing resulting from bioirrigation, bioturbation, and bottom turbidity currents. The profiles of dissolved and solid-phase geochemical constituents in the sediment provide indications as to specific diagenetic reactions prevailing (Froelich et al., 1979). However, reoxidation of reduced inorganic compounds often mask the primary reactions involved in carbon oxidation (Sørensen and Jørgensen, 1987; Hines et al., 1991). Together with the discrete geochemical zonation of the electron ac- ceptors, the independently executed metabolic rate measurements (Fig. 5) allowed us to evaluate the relative contribution of each terminal electron-accepting pathway with sediment depth.

Previous experimental studies that have quantified pathways of anaerobic carbon oxidation in subtidal marine sediments have generally determined the contributions of $\mathrm{Mn}$ and $\mathrm{Fe}$ reduction indirectly from the difference between rates of DIC production and sulfate reduction converted to carbon equivalents (e.g., Canfield et al., 1993b; Thamdrup and Canfield, 1996; Vandieken et al., 2006). The inferred rates of $\mathrm{Mn}$ and $\mathrm{Fe}$ reduction were further supported by the depth distribution of metal oxides and patterns of $\mathrm{Mn}^{2+}$ and $\mathrm{Fe}^{2+}$ accumulation in the pore water, but this could not be verified because the accumulation of particulate $\mathrm{Mn}$ (II) and Fe(II) which represents the overwhelming fraction of the reduced pools - was not quantified. Here, we combined the indirect approach with independent determination of $\mathrm{Mn}$ and Fe reduction rates. Thus, we obtained two separate estimates of anaerobic carbon oxidation rates: based on DIC production and on the sum of sulfate, $\mathrm{Fe}$, and $\mathrm{Mn}$ reduction converted to 


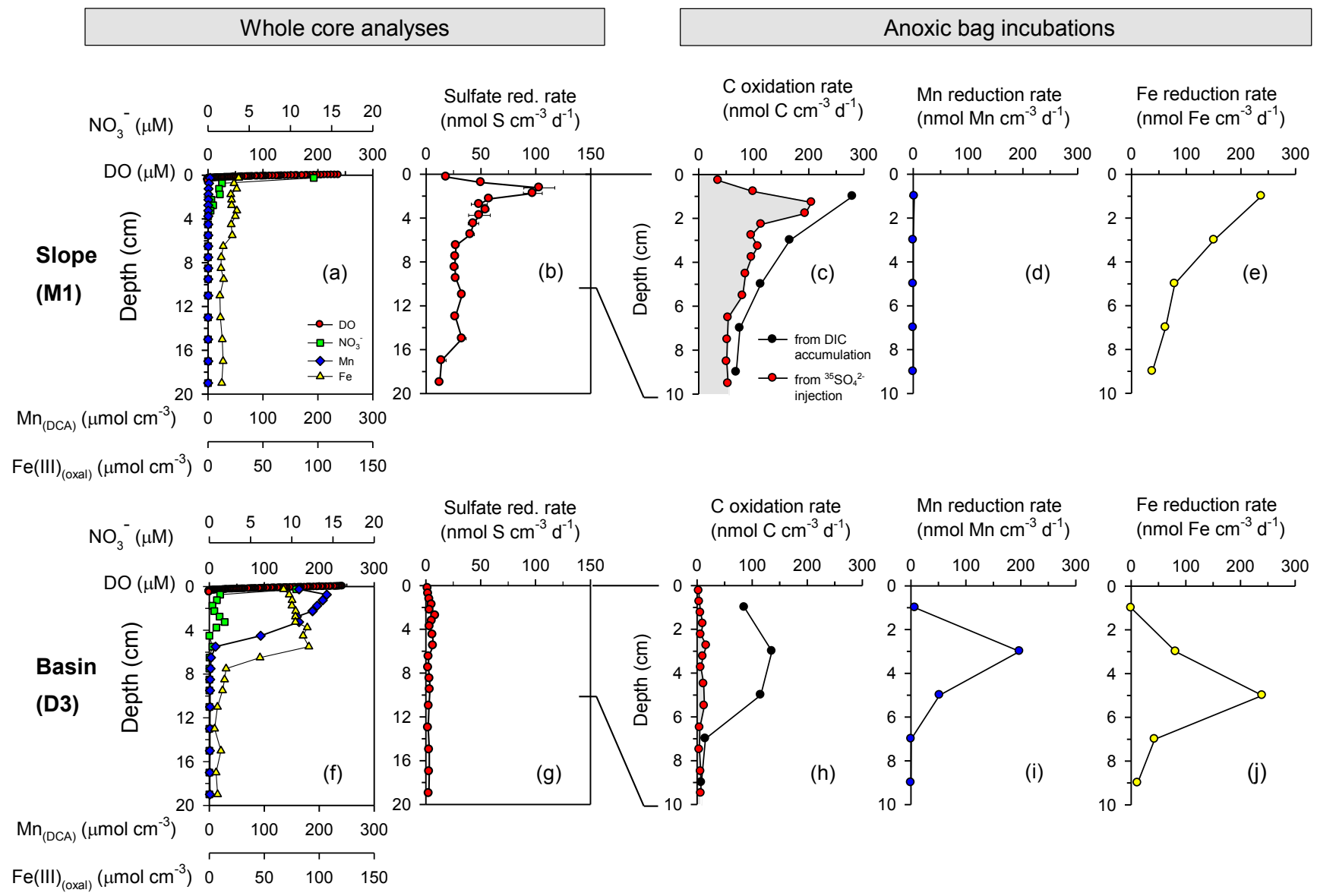

Figure 5. Vertical distribution of terminal electron acceptors $\left(\mathrm{O}_{2}, \mathrm{NO}_{3}^{-}, \mathrm{Mn}\right.$, and $\left.\mathrm{Fe}\right)$ and rates of sulfate reduction measured from whole core analyses, and rates of anaerobic carbon oxidation (DIC production rates), Mn reduction, and Fe reduction measured from anoxic bag incubations in Fig. 4. $\mathrm{C}_{\text {org }}$ by sulfate reduction in $(\mathbf{c}, \mathbf{h})$ was calculated from the stoichiometry of $2: 1$ of $\mathrm{C}_{\text {org }}$ oxidized to sulfate reduced.

carbon equivalents, respectively (Table 4). At M1, within the $0-10 \mathrm{~cm}$ depth interval, the average ratio between total anaerobic $\mathrm{C}_{\text {org }}$ oxidation rate $\left(10.7 \mathrm{mmol} \mathrm{C} \mathrm{m}^{-2} \mathrm{~d}^{-1}\right)$ and the $\mathrm{C}_{\text {org }}$ oxidation from DIC production $\left(14.0 \mathrm{mmol} \mathrm{C} \mathrm{m}^{-2} \mathrm{~d}^{-1}\right)$ was 0.77 (Table 4). Similarly, at D3, the average ratio between total anaerobic $\mathrm{C}_{\text {org }}$ oxidation $\left(6.79 \mathrm{mmol} \mathrm{m}^{-2} \mathrm{~d}^{-1}\right)$ and anaerobic DIC production $\left(7.22 \mathrm{mmol} \mathrm{m}^{-2} \mathrm{~d}^{-1}\right)$ was 0.94 . There was a good agreement between the two estimates with a ratio of total anaerobic $\mathrm{C}_{\text {org }}$ oxidation by $\mathrm{Mn}+\mathrm{Fe}+$ sulfate: DIC production for individual depth intervals of $0.8-1.2$ (Table 4) with the exception at the $0-2 \mathrm{~cm}$ depth of the slope site (M1), where the ratio was slightly lower, 0.66 , possibly due to a contribution from the $\mathrm{C}_{\text {org }}$ oxidation by nitrate reduction. The similarity of the two estimates across all incubations spanning a range of redox conditions provides confidence in our approach for calculating dissimilatory Mn and Fe reduction rates. Specifically, the good agreement indicates that the underlying assumptions concerning Mn adsorption and reactions of Fe(III) and sulfide are valid as first-order approximations. The general agreement further supports the validity of previous determinations of dissimilatory $\mathrm{Mn}$ and $\mathrm{Fe}$ reduction rates based on the difference between DIC production and $\mathrm{SO}_{4}^{2-}$ reduction (Canfield et al., 1993a, b; Thamdrup et al., 2000; Vandieken et al., 2006, 2014).

To elucidate the contribution of sulfate reduction in anaerobic carbon oxidation, the SRRs (Fig. 5b, g) were converted to carbon oxidation (Thamdrup and Canfield, 1996) and then compared to the DIC production rates from anoxic bag incubation (Fig. 5c, h). At the slope site (M1), the fraction of anaerobic $\mathrm{C}_{\text {org }}$ oxidation coupled to sulfate reduction increased with depth from $48 \%$ at $0-2 \mathrm{~cm}$ to $80 \%$ at $8-10 \mathrm{~cm}$ (Table 4). Thus, the excess $\mathrm{C}_{\text {org }}$ oxidation in the upper layers should be coupled to other electronaccepting processes. Indeed, the $\mathrm{C}_{\text {org }}$ oxidation by $\mathrm{Fe}$ reduction $\left(0.96 \mathrm{mmol} \mathrm{m}^{-2} \mathrm{~d}^{-1}\right)$ accounted for most of the remaining anaerobic $\mathrm{C}_{\mathrm{org}}$ oxidation (12-18\% of DIC production) at $0-8 \mathrm{~cm}$ depth, consistent with the distribution of Fe(III) decreasing from $>25 \mu \mathrm{mol} \mathrm{cm}{ }^{-3}$ near the surface (Fig. 6, Table 4). Mn reduction was of minor importance at M1 because of the low content of Mn oxide $\left(<3 \mu \mathrm{mol} \mathrm{cm}{ }^{-3}\right)$. Carbon oxidation coupled to aerobic respiration was estimated to $3.1 \mathrm{mmol} \mathrm{m}^{-2} \mathrm{~d}^{-1}$, corresponding to $18 \%$ of the 
Table 3. Depth-integrated rates $\left(\mathrm{mmol} \mathrm{m}^{-2} \mathrm{~d}^{-1}\right)$ of $\mathrm{Mn}$ reduction, Fe reduction, and sulfate reduction and the partitioning of abiotic and microbial Fe(III) reduction in total Fe(III) reduction with depth.

\begin{tabular}{|c|c|c|c|c|c|c|c|}
\hline \multirow[t]{2}{*}{ Station } & \multirow{2}{*}{$\begin{array}{r}\text { Depth } \\
\text { interval }(\mathrm{cm})\end{array}$} & \multirow{2}{*}{$\begin{array}{l}\mathrm{SO}_{4}^{2-} \\
\quad \text { red. }\end{array}$} & \multirow{2}{*}{$\begin{array}{l}\text { Mn } \\
\text { red. }\end{array}$} & \multirow{2}{*}{$\begin{array}{l}{ }^{\mathrm{a}} \text { Total } \\
\text { Fe(III) red. }\end{array}$} & \multicolumn{2}{|c|}{ Fe reduction by } & \multirow{2}{*}{$\begin{array}{l}\text { Fe red.(microbial) } \\
\text { Fe red.(abiotic) }\end{array}$} \\
\hline & & & & & $\begin{array}{l}{ }^{\mathrm{a}} \text { Abiotic } \\
\text { Fe red. }\end{array}$ & $\begin{array}{r}{ }^{\text {a }} \text { Microbial } \\
\text { Fe red. }\end{array}$ & \\
\hline \multirow[t]{6}{*}{ M1 } & $0-2$ & 1.35 & 0.04 & 4.75 & 0.90 & 3.86 & 4.28 \\
\hline & $2-4$ & 1.04 & - & 3.02 & 0.70 & 2.33 & 3.33 \\
\hline & $4-6$ & 0.84 & - & 1.58 & 0.56 & 1.21 & 2.16 \\
\hline & $6-8$ & 0.54 & - & 1.25 & 0.36 & 0.89 & 2.47 \\
\hline & $8-10$ & 0.53 & - & 0.77 & 0.36 & 0.41 & 1.14 \\
\hline & Sum $(0-10)$ & 4.30 & 0.04 & 11.4 & 2.88 & 8.70 & \\
\hline \multirow[t]{6}{*}{ D3 } & $0-2$ & 0.06 & $\mathrm{~b}_{3.19}$ & - & - & - & NA \\
\hline & $2-4$ & 0.11 & 3.96 & 1.63 & 0.07 & 1.56 & 22.3 \\
\hline & $4-6$ & 0.13 & 1.05 & 4.80 & 0.09 & 4.71 & 52.3 \\
\hline & $6-8$ & 0.06 & 0.01 & 0.86 & 0.04 & 0.83 & 20.8 \\
\hline & 8-10 & 0.07 & 0.00 & 0.24 & 0.05 & 0.19 & 3.80 \\
\hline & Sum $(0-10)$ & 0.43 & 8.21 & 7.53 & 0.25 & 7.29 & \\
\hline
\end{tabular}

\footnotetext{
a Stoichiometric equations were used to evaluate the relative significance of abiotic and microbial Fe reduction: abiotic reduction of $\mathrm{Fe}$ (III) by sulfide oxidation, $3 \mathrm{H}_{2} \mathrm{~S}+2 \mathrm{FeOOH}=2 \mathrm{FeS}+\mathrm{S}^{0}+4 \mathrm{H}_{2} \mathrm{O}$; microbial Fe(III) reduction = total Fe(III) reduction - abiotic $\mathrm{Fe}$ (III) reduction. ${ }^{\mathrm{b}}$ Back-calculated from the $\mathrm{C}$ oxidation by $\mathrm{Mn}$ reduction in the $0-2 \mathrm{~cm}$ interval in Table 4 using the stoichiometric equation, $2 \mathrm{MnO}_{2}+\mathrm{CH}_{2} \mathrm{O}+\mathrm{H}_{2} \mathrm{O}=2 \mathrm{Mn}^{2+}+\mathrm{HCO}_{3}^{-}+3 \mathrm{OH}^{-}$. "-" indicates that the process does not occur or is regarded as negligible at the depth interval based on the OPD for aerobic respiration and geochemical profiles or anoxic bag incubations for Mn(IV) and $\mathrm{Fe}(\mathrm{III})$ reduction. "NA" indicates that data are not available.
}

total aerobic + anaerobic oxidation, while the contributions of $\mathrm{Fe}$ and sulfate reduction to this total were 12 and $50 \%$, respectively (Table 4). As mentioned above, nitrate reduction/denitrification may contribute part of the unexplained $19 \%$ of carbon oxidation, but most of this imbalance likely reflects the combined uncertainties in the estimates of the individual pathways. Additionally, our partitioning of carbon oxidation pathways could be biased towards the anaerobic electron acceptors due to the use of the diffusive oxygen uptake (DOU) rather than total oxygen uptake (TOU), which will exceed DOU if bioirrigation is active (Glud, 2008). Bioirrigation was not determined at our sites, but the pore water profiles show no indication of strong irrigation (Fig. 2). An average DOU / TOU ratio of $\sim 0.6$ has been reported for sediments at $1.5-2.5 \mathrm{~km}$ depth (Glud, 2008). Using this ratio, and assuming that TOU is partitioned similarly as DOU between aerobic carbon oxidation and reoxidation, aerobic carbon oxidation would account for $25 \%$, while Fe and sulfate reduction would account for 11 and $46 \%$ of carbon oxidation, respectively. Thus, the potential bias from using DOU is not expected to affect the ranking of electron acceptors by quantitative importance $\left(\mathrm{SO}_{4}^{2-}>\mathrm{O}_{2}>\mathrm{Fe}(\mathrm{III})\right)$, and, as discussed further below, the partitioning of $\mathrm{C}_{\text {org }}$ oxidation at M1 falls within the range previously reported for continental margin sediments.

In contrast to $\mathrm{M} 1, \mathrm{C}_{\mathrm{org}}$ oxidation by sulfate reduction at the basin site (D3) accounted for only a small fraction $(<11 \%)$ of anaerobic $\mathrm{C}_{\mathrm{org}}$ oxidation at $0-6 \mathrm{~cm}$ interval and

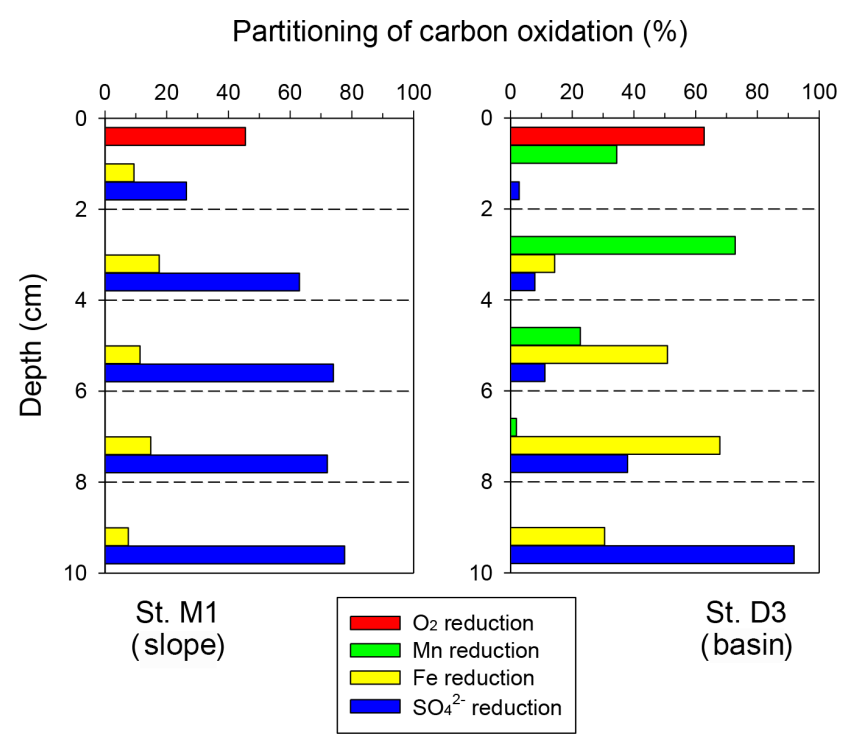

Figure 6. Depth variations in partitioning of each carbon oxidation pathway in total carbon oxidation at M1 and D3.

it only dominated carbon oxidation at $8-10 \mathrm{~cm}$ (Fig. $5 \mathrm{~h}$, Table 4). Oxygen and $\mathrm{NO}_{3}^{-}$were depleted within $3.6 \mathrm{~mm}$ and $1 \mathrm{~cm}$ depth of the sediment surface, respectively (Fig. 5f), while $\mathrm{Mn}$ and $\mathrm{Fe}$ (III) oxides were abundant at 0-4 and 0$6 \mathrm{~cm}$, respectively. Consistent with the abundance of electron acceptors, high rates of $\mathrm{Mn}$ and Fe reduction (Fig. 5i and j) 


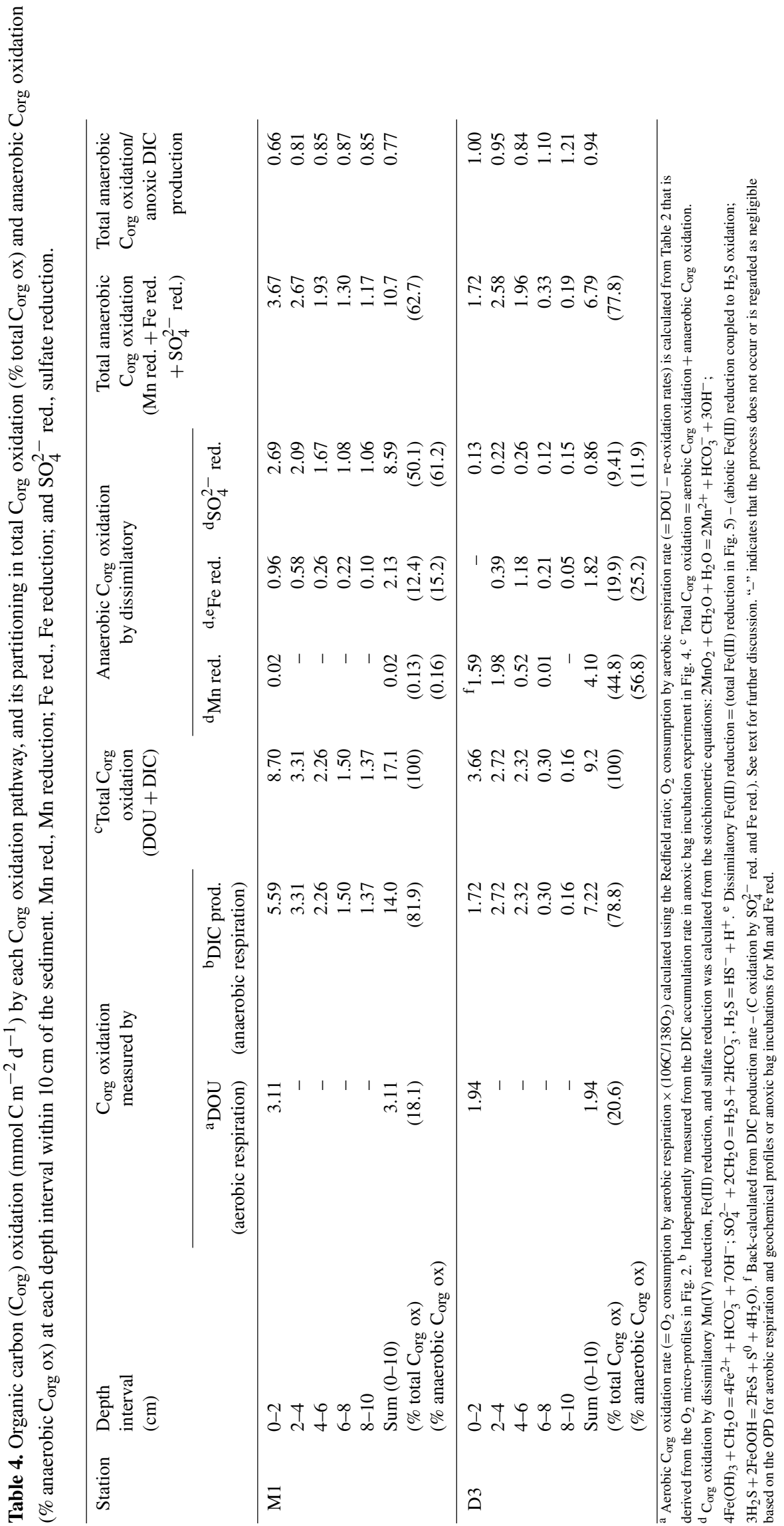


implied $\mathrm{Mn}$ and $\mathrm{Fe}$ reduction as the most significant $\mathrm{C}_{\text {org }}$ oxidation pathways to $6 \mathrm{~cm}$ depth. At $0-2 \mathrm{~cm}$ depth, $\mathrm{C}_{\text {org }}$ oxidation by aerobic respiration and $\mathrm{Mn}$ reduction accounted for 53 and $43 \%$ of total $\mathrm{C}_{\text {org }}$ oxidation, respectively (Fig. 6). At 2-4 cm, Mn reduction accounted for $73 \%$ of total $\mathrm{C}_{\text {org }}$ oxidation and $92 \%$ of anaerobic $\mathrm{C}_{\text {org }}$ oxidation (Table 4, Fig. 6). Its importance decreased to $22 \%$ at $4-6 \mathrm{~cm}$ due to lower $\mathrm{Mn}$ contents, while microbial $\mathrm{Fe}(\mathrm{III})$ reduction here contributed $51 \%$, and the partitioning of sulfate reduction increased to $11 \%$ (Fig. 6). Consequently, the relative distribution of each $\mathrm{C}_{\text {org }}$ oxidation pathway with depth at D3 (Fig. 6) matched well with the depth distribution of the respective electron acceptors (Fig. 5f). Overall, within the $10 \mathrm{~cm}$ depth sediment interval, Mn reduction and Fe reduction were the dominant $\mathrm{C}_{\text {org }}$ oxidation pathways comprising 45 and $20 \%$ of total carbon oxidation, respectively, at the $\mathrm{Mn}$ and $\mathrm{Fe}$ oxide-rich site in the center of the UB (Table 4). Correction for a potential underestimation of TOU, as discussed for M1, would reduce the contributions of $\mathrm{Mn}$ and $\mathrm{Fe}$ reduction slightly to 41 and $18 \%$, respectively.

Despite the high $\mathrm{Fe}$ oxide content at $0-4 \mathrm{~cm}$ at D3 (Fig. 5f), no solid $\mathrm{Fe}(\mathrm{II})_{(\text {oxal }}$ accumulation was observed at this depth range (Fig. 4). This indicates that Fe(III) reduction may not occur under these Mn oxide-rich conditions. Indeed, using acombination of 16S rRNA-stable isotope probing and geochemical analysis in three manganese oxide-rich sediments including the UB, Vandieken et al. (2012) identified bacteria related to Colwellia, Oceanospillaceae and Arcobacter as acetate-oxidizing bacteria that potentially reduce manganese, whereas no known iron reducers were detected in the Mn-rich sediment. Similarly, Thamdrup et al. (2000) found, in Mn oxide-rich Black Sea sediment, that the abundance of viable Fe-reducing bacteria in most probable number counts was low in comparison to $\mathrm{Mn}$ reducers and the addition of ferrihydrite did not stimulate Fe reduction, which implied that Fe reduction should be outcompeted by the Mn reduction process.

As manganese reduction is thermodynamically more favorable than iron and sulfate reduction, the $\mathrm{Mn}^{2+}$ liberation (Fig. 4) likely resulted from dissimilatory $\mathrm{Mn}$ reduction. Nonetheless, Mn reduction estimated from the increase in $\mathrm{Mn}^{2+}$ at $0-4 \mathrm{~cm}$ interval at D3 (Fig. 4) could be due to oxidation of $\mathrm{Fe}^{2+}$ or sulfide. $\mathrm{Fe}^{2+}$ may readily react with $\mathrm{Mn}$ oxides (Meyers and Nealson, 1988; Lovley and Phillips, 1988) by the reaction $2 \mathrm{Fe}^{2+}+\mathrm{MnO}_{2}+4 \mathrm{H}_{2} \mathrm{O}=\mathrm{Mn}^{2+}+2 \mathrm{Fe}(\mathrm{OH})_{3}+2 \mathrm{H}^{+}$. However, in the Mn oxide-rich sediment of the Skagerrak, Canfield et al. (1993b) revealed that the addition of Ferrozine, a strong complexation agent for $\mathrm{Fe}^{2+}$, had no inhibitory effect on the $\mathrm{Mn}^{2+}$ liberation, indicating that the chemical reaction of $\mathrm{MnO}_{2}$ with $\mathrm{Fe}^{2+}$ generated by $\mathrm{Fe}$ reduction was not responsible for the accumulation of $\mathrm{Mn}^{2+}$.

Despite the anoxic conditions and nitrate depletion during the bag incubation, $\mathrm{Mn}$ reduction rates at $0-2 \mathrm{~cm}$ depth (Fig. 5i) based on $\mathrm{Mn}^{2+}$ accumulation were substan- tially lower than the rates inferred from DIC accumulation (Fig. 5h). A similar discrepancy was previously observed for the uppermost part of the Mn reduction zone (Thamdrup et al., 2000) and is likely explained by particularly strong sorption of $\mathrm{Mn}^{2+}$ to fresh Mn oxide surfaces, which is not included in the adsorption coefficient used here. Low $\mathrm{Mn}^{2+}$ together with the rapid decrease in nitrate at $0-2 \mathrm{~cm}$ depth at D3 (Fig. 2f, g) also suggested that dissolved reduced manganese might act as a reducing agent for nitrate, as was suggested by Aller et al. (1998) in the Panama Basin and Mogollón et al. (2016) in the deep-sea sediment of the ClarionClipperton fracture zone in the northeast equatorial Pacific.

Previous estimation of denitrification in $0-2 \mathrm{~cm}$ depth of the UB ranged from 0.01 to $0.17 \mathrm{mmol} \mathrm{N} \mathrm{m}^{-2} \mathrm{~d}^{-1}$ (Lee, 2009), which is equivalent to a $C_{\text {org }}$ oxidation of $0.013-$ $0.213 \mathrm{mmol} \mathrm{C} \mathrm{m}^{-2} \mathrm{~d}^{-1}$ using the stoichiometric equation of $4 \mathrm{H}^{+}+5 \mathrm{CH}_{2} \mathrm{O}+4 \mathrm{NO}_{3}^{-}=5 \mathrm{CO}_{2}+2 \mathrm{~N}_{2}+7 \mathrm{H}_{2} \mathrm{O}$. Based on the average, the contribution of carbon oxidation by denitrification $\left(0.11 \mathrm{mmol} \mathrm{C} \mathrm{m}^{-2} \mathrm{~d}^{-1}\right)$ should be minor at the basin site $\left(\leq 3 \%\right.$ of total $\mathrm{C}_{\text {org }}$ oxidation at $0-2 \mathrm{~cm} ; \sim 1 \%$ of integrated $\mathrm{C}_{\text {org }}$ oxidation). This is consistent with the general consensus that $\mathrm{C}_{\text {org }}$ oxidation by denitrification is of little importance in most marine sediments (Sørensen et al., 1979; Canfield et al., 1993a; Trimmer and Engström, 2011). Denitrification may be even further suppressed in Mn-rich sediments due to competitive inhibition from Mn reduction (Trimmer et al., 2013).

\section{2 $\mathrm{C}_{\text {org }}$ oxidation dominated by manganese reduction in the $\mathrm{UB}$}

Microbial Fe reduction has been quantified directly in sediments of various coastal oceans (Gribsholt et al., 2003; Kostka et al., 2002a, b; Hyun et al., 2007, 2009b) and indirectly in deeper continental margins (Thamdrup and Canfield, 1996; Jensen et al., 2003; Kostka et al., 1999). Earlier estimation from 16 different continental margin sediments indicated that $\mathrm{Fe}(\mathrm{III})$ reduction contributed $22 \%$ on average to anaerobic carbon oxidation (Thamdrup, 2000). Thus, the contributions from $\mathrm{Fe}(\mathrm{III})$ reduction of 12 and $20 \%$ of anaerobic $\mathrm{C}_{\text {org }}$ oxidation on the slope (M1) and in the basin (D3) of the UB (Table 4) fall in the range of the previous indirect estimates.

Unlike Fe reduction, direct estimation of manganese reduction rates is not easy, mainly because of the restriction of the process to a thin surface layer (Sundby and Silverberg, 1985), the rapid reduction of manganese oxides with $\mathrm{H}_{2} \mathrm{~S}$ and $\mathrm{Fe}^{2+}$ (Postma, 1985; Burdige and Nealson, 1986; Kostka et al., 1995; Lovley and Phillips, 1988), and the adsorption of $\mathrm{Mn}^{2+}$ to Mn oxide surface (Canfield et al., 1993b). For that reason, only two studies, from the Skagerrak and Black Sea, are available for direct comparison on the partitioning of $\mathrm{Mn}$ reduction. The process has also been indicated to be of importance in the Panama Basin based on diagenetic modeling (Aller, 1990) and at some Arctic shelf sites 
where it was, however, not quantified separately from Fe reduction (Vandieken et al., 2006; Nickel et al., 2008). Mn reduction was responsible for over $90 \%$ of total $\mathrm{C}_{\text {org }}$ oxidation at $600 \mathrm{~m}$ depth in the Skagerrak (Canfield et al., 1993b), and accounted for $13-45 \%$ of anaerobic $\mathrm{C}_{\text {org }}$ oxidation in the Black Sea shelf sites at $60-130 \mathrm{~m}$ of water depth (Thamdrup et al., 2000). To our knowledge, this report of $\mathrm{C}_{\text {org }}$ oxidation dominated by $\mathrm{Mn}$ reduction comprising $45 \%$ of total $\mathrm{C}_{\mathrm{org}}$ oxidation and $57 \%$ of anaerobic $\mathrm{C}_{\text {org }}$ respiration in the center of the UB (Table 4) represents the first from deep-offshore basin of the eastern Asian marginal seas.

The difference in partitioning of $\mathrm{Mn}$ reduction in $\mathrm{C}_{\text {org }}$ oxidation between the UB, Black Sea, and Skagerrak reflects the close relationship between Mn oxide content in the sediment and Mn reduction (Thamdrup et al., 2000). From the vertical distribution of electron acceptors (Fig. 5f) and contribution of each $\mathrm{C}_{\text {org }}$ oxidation pathway with depth (Fig. 6), it is apparent that the availability of $\mathrm{Mn}$ (IV) largely controls the relative contribution to C oxidation. In the Skagerrak, the Mn oxides are abundant in high content down to $10 \mathrm{~cm}$ depth (Canfield et al., 1993b), whereas Mn oxides in the Black Sea and the Ulleung Basin were enriched only down to 2 and $4 \mathrm{~cm}$, respectively (Thamdrup et al., 2000; Fig. 2g). Using the available data set for the three marine sediments, we further plotted the relative contribution of manganese reduction to anaerobic carbon oxidation as a function of $\mathrm{Mn}$ oxide content to expand data from Thamdrup (2000) (Fig. 7). The plot indicates saturation kinetics with a close correlation between $\mathrm{Mn}$ oxide content and the importance of $\mathrm{Mn}$ reduction at low contents. Curve fitting yields a content of $\mathrm{MnO}_{2}$ at $50 \%$ of contribution of manganese reduction to to-

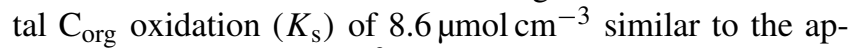
proximately $10 \mu \mathrm{mol} \mathrm{cm}{ }^{-3}$ suggested before (Thamdrup et al., 2000). This indicates that $\mathrm{Mn}$ reduction can be a dominant $\mathrm{C}_{\text {org }}$ oxidation process even at low contents of Mn oxides compared to those found at UB. Manganese enrichments of this magnitude have been reported for several locations on the continental margins and in deep basins (Murray et al., 1984; Gingele and Kasten, 1994; Gobeil et al., 1997; Haese et al., 2000; Mouret et al., 2009; Magen et al., 2011; Macdonald and Gobeil, 2012; Mewes et al., 2014) in addition to the relatively few places where dissimilatory $\mathrm{Mn}$ reduction was already indicated to be of importance, as discussed above. Thus, the process may be of more widespread significance, particularly in deep basin settings such as UB that allow geochemical focusing of manganese.

\subsection{Source of high Mn oxide content}

The strong enrichment of $\mathrm{Mn}$ in the UB surface sediment is primarily of diagenetic origin as indicated by just slightly higher Mn contents at depth in the sediment at D3 (mean $1.1 \mu \mathrm{mol} \mathrm{cm}{ }^{-3}$ at $10-20 \mathrm{~cm}$ depth) compared to M1 $\left(0.45 \mu \mathrm{mol} \mathrm{cm}{ }^{-3}\right)$ (Fig. 2) combined with higher sediment accumulation rates at the slope $\left(0.15-0.3 \mathrm{~cm}_{\text {year }}{ }^{-1}\right)$ than in

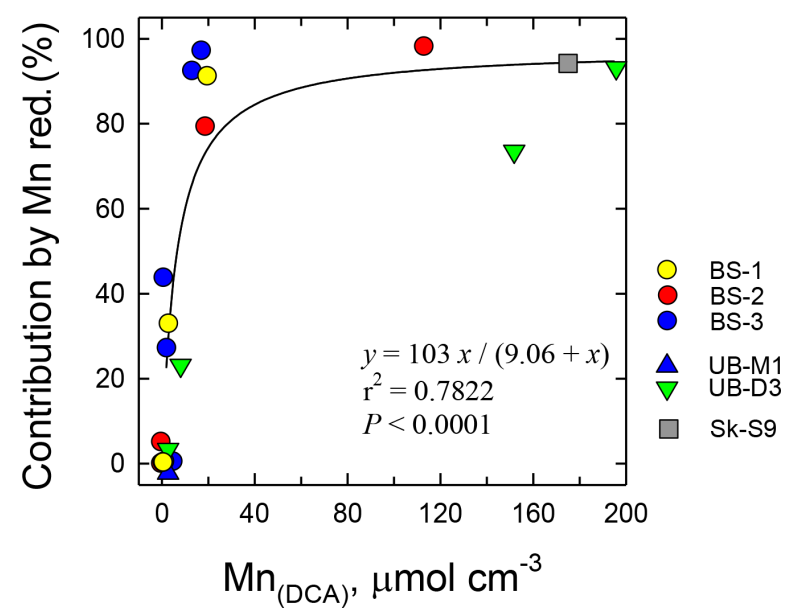

Figure 7. The relative contribution of Mn reduction to anaerobic carbon oxidation as a function of the content of $\mathrm{Mn}_{(\mathrm{DCA})}$ at three different sites: BS, Black Sea (Thamdrup et al., 2000); UB, Ulleung Basin (This study); Sk, Skagerrak (Canfield et al., 1993b).

the basin $\left(0.07 \mathrm{~cm} \mathrm{year}^{-1}\right.$; Cha et al., 2005). Thus, the burial flux of $\mathrm{Mn}$, and thereby the net input assuming steady-state deposition, is similar or higher at M1 compared to D3. Furthermore, $\mathrm{Mn}$ is likely subject to geochemical focusing in the basin as Mn depositing at shallower depths is reductively mobilized and incompletely oxidized in the thin oxic surface layer, resulting in release to the water column and net downslope transport, as inferred in other ventilated basins (Sundby and Silverberg, 1985; Canfield at al., 1993b; Schaller and Wehrli, 1997). A diagenetic source of Mn enrichment was also concluded in previous studies (Yin et al., 1989; Cha et al., 2007; Choi et al., 2009). The Mn remaining and being buried at M1 likely represents unreactive detrital forms to a larger extent than at D3 (Cha et al., 2007). Adopting the sediment accumulation rate of $0.07 \mathrm{~cm} \mathrm{year}^{-1}$ in the UB determined at a station $50 \mathrm{~km}$ from D3 (Cha et al., 2005), the average $\mathrm{Mn}_{(\mathrm{DCA})}$ content of $1.1 \mu \mathrm{mol} \mathrm{cm} \mathrm{cm}^{-3}$ at $10-20 \mathrm{~cm}$ depth (Fig. 2g) corresponds to a flux for permanent burial of $0.002 \mathrm{mmol} \mathrm{m}^{-2} \mathrm{~d}^{-1}$ or just $0.03 \%$ of the $\mathrm{Mn}$ reduction rate (Table 3) - i.e., an Mn atom is recycled 3800 times before it finally gets buried, first by stripping from the particles that settle to the seafloor and subsequently, over and over, by reductive dissolution of the $\mathrm{Mn}$ oxides that from by reoxidation in the oxic surface layer (or, potentially, in the nitrate zone; Aller et al., 1998; Mogollón et al., 2016). This is a much more extensive recycling than found in the Mn sediment of Skagerrak (130-260 times; Canfield et al., 1993b). The difference results mainly from a much higher burial flux of Mn (as authigenic $\mathrm{Mn}[\mathrm{II}])$ in the Skagerrak $\left(\sim 40 \mu \mathrm{mol} \mathrm{cm}{ }^{-3}\right.$; Canfield et al., 1993b). The reason that little, if any, authigenic $\mathrm{Mn}(\mathrm{II})$ is buried in the UB is not clear.

As noted in previous studies (Aller, 1990; Canfield et al., 1993b), high contributions of $\mathrm{Mn}$ and Fe reduction to carbon oxidation in offshore sediments require physi- 
cal mixing, which typically occurs through bioturbation. This is also the case for the UB, where the burial flux from the oxic surface layer into the Mn reduction zone corresponded to $0.4 \mathrm{mmol} \mathrm{m}^{-2} \mathrm{~d}^{-1}$ or $5 \%$ of the Mn reduction rate $\left(213 \mu \mathrm{mol} \mathrm{cm}{ }^{-3} \times 0.07 \mathrm{~cm}_{\text {year }}{ }^{-1}\right)$. Bioturbation has previously been inferred, but not quantified, from ${ }^{210} \mathrm{~Pb}$ profiles in the UB (Cha, 2002), and thin polychaete worms were observed during our sampling. Assuming bioturbation to be a diffusive process, we estimate, in a similar manner as in the previous studies and based on the average gradient in $\mathrm{Mn}_{(\mathrm{DCA})}$ from $0.5-1$ to $7-8 \mathrm{~cm}$, that the $\mathrm{Mn}$ reduction rate would be supported at a biodiffusion coefficient of $9.5 \mathrm{~cm}^{2}$ year $^{-1}$. This value is 3.6 times lower than the coefficient estimated for the Skagerrak (Canfield et al., 1993b) and consistent with estimates for other sediments with similar deposition rates (Boudreau, 1994). The estimated biodiffusion coefficient $(\mathrm{Db})$ of $9.5 \mathrm{~cm}^{2}$ year ${ }^{-1}$ at Site D3 corresponds to $\sim 2 \%$ of the molecular diffusion coefficient of oxygen $\left(388 \mathrm{~cm}^{2}\right.$ year $\left.^{-1}\right)$. Judging from the absence of major fauna in the UB sediments, the mixing is brought about by small organisms with each individual affecting only a small area relative to the size of our cores, and the $\mathrm{Db}$ averaging many of these small and local but frequent events. Under such conditions, bioturbation can drive Mn cycling in the UB without substantial smearing of the redox zonation. Similarly, Hyacinthe et al. (2001) found that well-defined profiles can be observed in both sediments with low and high bioactivity in the Bay of Biscay.

\subsection{The UB as a biogeochemical hotspot}

The SRRs measured in this study $\left(0.43-4.29 \mathrm{mmol} \mathrm{m}^{-2} \mathrm{~d}^{-1}\right)$ are higher than those measured in productive systems such as the Benguela upwelling system in the southeastern Atlantic (0.14-1.39 $\mathrm{mmol} \mathrm{m}^{-2} \mathrm{~d}^{-1}$; Ferdelman et al., 1999), and even comparable to those reported at the Chilean (2.7$4.8 \mathrm{mmol} \mathrm{m}^{-2} \mathrm{~d}^{-1}$; Thamdrup and Canfield, 1996) and Peruvian upwelling system $\left(5.2 \mathrm{mmol} \mathrm{m}^{-2} \mathrm{~d}^{-1}\right.$; Fossing, 1990) at a similar depth range of $1000-2500 \mathrm{~m}$. The total anaerobic DIC production rates at the slope $\left(14.0 \mathrm{mmol} \mathrm{m}^{-2} \mathrm{~d}^{-1}\right)$ and basin site $\left(7.2 \mathrm{mmol} \mathrm{m}^{-2} \mathrm{~d}^{-1}\right)$ were also comparable to those measured at the same depth range of a Chilean upwelling site (9.2-11.6 $\mathrm{mmol} \mathrm{m}^{-2} \mathrm{~d}^{-1}$ ) (Thamdrup and Canfield, 1996). Since rates of benthic carbon oxidation are largely controlled by the supply of $\mathrm{C}_{\text {org }}$ (Canfield et al., 2005), a high $\mathrm{C}_{\text {org }}$ flux reflected in the high $\mathrm{C}_{\text {org }}$ content ( $>2.5 \%$, dry wt.) in the sediment of the UB (Table 1) is likely to explain the high metabolic activities. A similar high $\mathrm{C}_{\text {org }}$ content as in the UB is rarely found in deep-sea sediment underlying oxic bottom water at depths exceeding $2000 \mathrm{~m}$, except for a Chilean upwelling site (Lee et al., 2008). This high $\mathrm{C}_{\text {org }}$ content in the UB is mainly associated with the combination of enhanced biological production resulting from the formation of coastal upwelling (Hyun et al., 2009a), enhanced new production in summer (Kwak et al., 2013), occurrence of an intrathermo- cline eddy resulting in the extraordinary subsurface chlorophyll $a$ maximum (Kim et al., 2012), high $\mathrm{C}_{\text {org }}$ accumulation rates exceeding $2 \mathrm{~g} \mathrm{C} \mathrm{m}^{-2}$ year $^{-1}$ (Lee et al., 2008), and high export production (Kim et al., 2009). Consequently, high benthic mineralization resulting from the high $\mathrm{C}_{\mathrm{org}}$ in the sediment implied that the UB is a biogeochemical hotspot where significant turnover of organic matter and nutrient regeneration occur.

Recent oceanographic observations revealed that the gradual deoxygenation and warming of the bottom water of the East Sea over the last 30 years have resulted in an $\sim 10 \%$ decrease in dissolved oxygen and $\sim 0.04{ }^{\circ} \mathrm{C}$ increase in potential temperature (Kim et al., 2001; Gamo, 2011; Gamo et al., 2014). Benthic metabolism and respiratory $\mathrm{C}_{\text {org }}$ oxidation coupled to various terminal electron-accepting processes in the sediments are largely controlled by the combination of $\mathrm{O}_{2}$ content, temperature, and biological production overlying the water column (Canfield et al., 2005). It is thus important to monitor any changes in the rates and partitioning of $\mathrm{C}_{\text {org }}$ oxidation to better understand and predict the variations in biogeochemical cycles of carbon, nutrients, and metals potentially associated with long-term climatic changes in the UB, the biogeochemical hotspot of the East Sea.

\section{Conclusions}

Surface sediments of the Ulleung Basin (UB) in the East Sea are characterized by a high $\mathrm{C}_{\text {org }}$ content $(>2.5 \%$, dry wt.), high contents of Fe oxides (up to $100 \mu \mathrm{mol} \mathrm{cm} \mathrm{cm}^{-3}$ ), and very high contents of Mn oxides $\left(>200 \mu \mathrm{mol} \mathrm{cm} \mathrm{cm}^{-3}\right)$. We show that microbial $\mathrm{Mn}$ and $\mathrm{Fe}$ reduction are the dominant $\mathrm{C}_{\text {org }}$ oxidation pathways, comprising 45 and $20 \%$ of total $\mathrm{C}_{\text {org }}$ oxidation, respectively. The high $\mathrm{Mn}$ content results from highly efficient recycling through reoxidation with very low permanent burial of authigenic Mn(II) phases. The basin topography may ensure that any $\mathrm{Mn}^{2+}$ escaping to the overlying water returns to the sediment after reprecipitation. The relative importance of $\mathrm{Mn}$ reduction to $\mathrm{C}_{\mathrm{org}}$ oxidation displays saturation kinetics with respect to $\mathrm{Mn}$ oxide content with a low half-saturation value $\left(8.6 \mu \mathrm{mol} \mathrm{cm}{ }^{-3}\right)$, which further implies that $\mathrm{Mn}$ reduction can be a dominant $\mathrm{C}_{\text {org }}$ oxidation process in sediments with lower $\mathrm{MnO}_{2}$ content, and thereby that the process might be more important in continental margin and deep basin sediments than previously thought. Vertical distributions of the major terminal electron acceptors such as $\mathrm{O}_{2}$, nitrate, and $\mathrm{Mn}$ and $\mathrm{Fe}$ oxides were systematically zonated with discrete sequential depletion according to the order of decreasing energy yield for $\mathrm{C}_{\text {org }}$ oxidation, which are not sharply separated in most aquatic sediments due to, for example, sediment heterogeneity and mixing resulting from bioirrigation, bioturbation, and bottom turbidity currents. High benthic mineralization resulting from the high $\mathrm{C}_{\text {org }}$ content in the sediment implied that the UB is a biogeo- 
chemical hotspot where significant turnover of organic matter and nutrient regeneration occur.

Author contributions. Jung-Ho Hyun, as the first author and leader of the Korean research group, designed the original experiments and conducted most writing; Sung-Han Kim, Jin-Sook Mok, and Hyeyoun Cho participated in onboard research activities and analytical processes; Verona Vandieken participated in onboard research and was actively involved in the discussion of the manuscript; Tongsup Lee, as project manager of the EAST-1 program, participated in discussion of the results; Bo Thamdrup, as leader of the Danish research group, collaborated with Jung-Ho Hyun in designing the experiments and writing and discussing the manuscript.

Competing interests. The authors declare that they have no conflict of interest.

Acknowledgements. This research was a part of the projects titled Korean Long-term Marine Ecological Researches (K-LTMER) and Deep Water Circulation and Material Cycling in the East Sea (EAST-II) funded by the Korean Ministry of Oceans and Fisheries, and was also supported by the National Research Foundation of Korea (NRF-2012-013-2012S1A2A1A01030760) in collaboration with the Danish Council for Independent Research and the Danish National Research Foundation (DNRF53). The authors thank S. Pantoja (handling editor), S. Kasten and the two anonymous reviewers for their comments that improved the earlier version of the manuscript.

Edited by: S. Pantoja

Reviewed by: S. Kasten and two anonymous referees

\section{References}

Aller, R. C.: Bioturbation and manganese cycling in hemipelagic sediments, Philos. T. R. Soc. Lond. A, 331, 51-68, 1990.

Aller, R. C., Hall, P. O. J., Rude, P. D., and Aller, J. Y.: Biogeochemical heterogeneity and suboxic diagenesis in hemipelagic sediments of the Panama Basin, Deep-Sea Res. Pt. I, 45, 133165, 1998.

Berg, P., Risgaard-Petersen, N., and Rysgaard, S.: Interpretation shelf and slope: A comparison of in situ microelectrode and chamber flux measurements, Limnol. Oceanogr., 37, 614-629, 1998.

Boudreau, B. P.: Is burial velocity a master parameter for bioturbation?, Geochim. Cosmochim. Ac., 58, 1243-1249, 1994.

Bowles, M. W., Mogollón, J. M., Kasten, S., Zabel, M., and Hinrichs, K. U.: Global rates of marine sulfate reduction and implications for sub-sea-floor metabolic activities, Science, 344, 889891, 2014.

Burdige, D. J. and Nealson, K. H.: Chemical and microbiological studies of sulfide-mediated manganese reduction, Geomicrobiol. J., 4, 361-387, 1986.

Canfield, D. E., Jørgensen, B. B., Fossing, H., Glud, R., Gundersen, J., Rasing, N. B., Thamdrup, B., Hansen, J. W., Nielsen, L. P., and Hall, P. O. J.: Pathways of organic carbon oxidation in three continental margin sediments, Mar. Geol., 113, 27-40, 1993a.

Canfield, D. E., Thamdrup, B., and Hansen, J. W.: The anaerobic degradation of organic matter in Danish coastal sediments: iron reduction, manganese reduction, and sulfate reduction, Geochim. Cosmochim. Ac., 57, 3867-3883, 1993 b.

Canfield, D. E., Thamdrup, B., and Kristensen, E. (Eds.): Aquatic geomicrobiology, Elsevier, San Diego, 640 pp., 2005.

Cha, H. J.: Geochemistry of surface sediments and diagenetic redistribution of phosphorus in the southwestern East Sea, $\mathrm{PhD}$ thesis, Seoul National Univ., Seoul, Korea, 190 pp., 2002.

Cha, H. J., Lee, C. B., Kim, B. S., Choi, M. S., and Ruttenberg, K. C.: Early diagenetic redistribution and burial of phosphorus in the sediments of the southwestern East Sea (Japan Sea), Mar. Geol., 216, 127-143, 2005.

Cha, H. J., Choi, M. S., Lee, C.-B., and Shin, D.-H.: Geochemistry of surface sediments in the southwestern East/Japan Sea, J. Asian Earth Sci., 29, 685-697, 2007.

Choi, Y. J., Kim, D. S., Lee, T. H., and Lee, C. B.: Estimate of manganese and iron oxide reduction rates in slope and basin sediments of Ulleung Basin, East Sea, J. Korean Soc. Oceanogr., 14, 127-133, 2009.

Chough, S. K., Lee, H. J., and Yoon, S. H. (Eds.): Marine Geology of Korean Seas, 2nd Edn., Elsevier, Amsterdam, 2000.

Cline, J. D.: Spectrophotometric determination of hydrogen sulfide in natural waters, Limnol. Oceanogr., 14, 454-458, 1969.

D’Hondt, S., Inagaki, F., Zarikian, C. A., Abrams, L. J., Dubois, N., Engelhardt, T., Evans, H., Ferdelman, T., Gribsholt, B., Harris, R. N., Hoppie, B. W., Hyun, J.-H., Kallmeyer, j., Kim, J., Lynch, J. E., McKinley, C. C., Mitsunobu, S., Morono Y., Murray, R. W., Pockalny, R., Sauvage, J., Shimono, T., Shiraishi, F., Smith, D. C., Smith-Duque, C. E., Spivack, A. J., Steinsbu, B. O., Suzuki, Y., Szpak, M., Toffin, L., Uramoto, G., Yamaguchi, Y. T., Zhang, G.-I., Zhang, X.-H., and Ziebis, W.: Presence of oxygen and aerobic communities from sea floor to basement in deep-sea sediments, Nat. Geosci., 8, 299-304, 2015.

Ferdelman, T. G., Fossing, H., Neumann, K., and Schulz, H. D.: Sulfate reduction in surface sediments of the southeast Atlantic continental margin between $15^{\circ} 38^{\prime} \mathrm{S}$ and $27^{\circ} 57^{\prime} \mathrm{S}$ (Angola and Namibia), Limnol. Oceanogr., 44, 650-661, 1999.

Fossing, H.: Sulfate reduction in shelf sediments in the upwelling region off Central Peru, Cont. Shelf Res., 10, 355-367, 1990.

Fossing, H. and Jørgensen, B. B.: Measurement of bacterial sulfate reduction in sediments: evaluation of a single-step chromium reduction method, Biogeochemistry, 8, 205-222, 1989.

Fossing, H., Ferdelman, T. G., and Berg, P.: Sulfate reduction and methane oxidation in continental margin sediments influenced by irrigation (South-East Atlantic off Namibia), Geochim. Cosmochim. Ac., 64, 897-910, 2000.

Froelich, P. N., Klinkhammer, G. P., Bender, M. L., Luedtke, N. A., Heath, G.R., Cullen, D., Dauphin, P., Hammond, D., Hartman, B., and Maynard, V.: Early oxidation of organic matter in pelagic sediments of the eastern equatorial Atlantic: suboxic diagenesis, Geochim. Cosmochim. Ac., 43, 1075-1090, 1979.

Gamo, T.: Dissolved oxygen in the bottom water of the Sea of Japan as a sensitive alarm for global climatic change, Trend Anal. Chem., 30, 1308-1319, 2011.

Gamo, T., Nakayama, N., Takahata, N., Sano, Y., Zhang, J., Yamazaki, E., Taniyasu, S., and Yamashita, N.: The Sea of Japan 
and its unique chemistry revealed by time-series observations over the last 30 Year, Monogr. Environ. Earth Planets, 2, 1-22, 2014.

Gingele, F. X. and Kasten, S.: Solid-phase manganese in Southeast Atlantic sediments Implications for the paleoenvironment, Mar. Geol., 121, 317-332, 1994.

Glud, R. N.: Oxygen dynamics of marine sediments, Mar. Biol. Res., 4, 243-289, 2008.

Gobeil, C., Macdonald, R. W., and Sundby, B.: Diageneticseparation of cadmium and manganese in suboxiccontinental margin sediments, Geochim. Cosmochim. Ac., 61, 4647-4654, 1997.

Gribsholt, B., Kostka, J. E., and Kristensen, E.: Impact of fiddler crabs and plant roots on sediment biogeochemistry in a Georgia saltmarsh, Mar. Ecol.-Prog. Ser., 259, 237-251, 2003.

Haese, R. R., Schramm, J., Rutgers Van Der Loeff, M. M., and Schulz, H. D.: A comparative study of iron and manganese diagenesis in continental slope and deep sea basin sediments off Uruguay (SW Atlantic), Int. J. Earth Sci., 88, 619-629, 2000.

Hall, P. O. and Aller, R. C.: Rapid small-volume, flow injection analysis for $\mathrm{CO}_{2}$ and $\mathrm{NH}_{4}^{+}$in marine and freshwaters, Limnol. Oceanogr., 37, 113-119, 1992.

Hansen, C., Zabel, M., and Schulz, H. N.: Benthic cycling of oxygen, nitrogen, and phosphorus, in: Marine Geochemistry, edited by: Schulz, H. D. and Zabel, M., Springer-Verlag, Berlin, Heidelberg, NY, 207-240, 2006.

Hansen, J. W., Thamdrup, B., and Jørgensen, B. B.: Anoxic incubation of sediment in gas-tight plastic bags: a method for biochemical process studies, Mar. Ecol.-Prog. Ser., 208, 273-282, 2000.

Hines, M. E., Bzylinski, D. A., Tugel, J. B., and Lyons, W. B.: Anaerobic microbial biogeochemistry in sediments from two basins in the Gulf of Maine: evidence for iron and manganese reduction, Estuar. Coast. Shelf S., 32, 313-324, 1991.

Hyacinthe, C., Anschutz, P., Carbonel, P., Jouanneau, J.-M., Jorissen, F. J.: Early diagenetic processes in the muddy sediments of the Bay of Biscay, Mar. Geol., 177, 111-128, 2001.

Hyun, J.-H., Smith, A. C., and Kostka, J. E.: Relative contributions of sulfate- and iron(III) reduction to organic matter mineralization and process controls in contrasting habitats of the Georgia saltmarsh, Appl. Geochem., 22, 2637-2651, 2007.

Hyun, J.-H., Kim, D., Shin, C.-W., Noh, J.-H., Yang, E.-J., Mok, J.S., Kim, S.-H., Kim, H.-C., and Yoo, S.: Enhanced phytoplankton and bacterioplankton production coupled to coastal upwelling and an anticyclonic eddy in the Ulleung basin, East Sea, Aquat. Microbiol. Ecol., 54, 45-54, 2009a.

Hyun, J.-H., Mok, J.-S., Cho, H.-Y., Kim, S.-H., and Kostka, J. E.: Rapid organic matter mineralization coupled to iron cycling in intertidal mud flats of the Han River estuary, Yellow Sea, Biogeochemistry, 92, 231-245, 2009b.

Hyun, J.-H., Mok, J.-S., You, O.-R., Kim, D., and Choi, D. L.: Variations and controls of sulfate reduction in the continental slope and rise of the Ulleung basin off the southeast Korean upwelling system in the East Sea, Geomicrobiol. J., 27, 1-11, 2010.

Jahnke, R. A. and Jahnke, D. B.: Rates of C, N, P and Si recycling and denitrification at the US mid-Atlantic continental slope depocenter, Deep-Sea Res. Pt. I, 47, 1405-1428, 2000.

Jahnke, R. A., Emerson, S. R., and Murray, J. W.: A model of oxygen reduction, denitrification, and organic matter mineralization in marine sediments, Limnol. Oceanogr., 27, 610-623, 1982.
Jahnke, R. A., Reimers, C. E., and Craven, D. B.: Intensification of recycling of organic matter at the sea floor near ocean margins, Nature, 348, 50-54, 1990.

Jensen, M. M., Thamdrup, B., Rysgaard, S., Holmer, M., and Fossing, H.: Rates and regulation of microbial iron reduction in sediments of the Baltic-North Sea transition, Biogeochemistry, 65, 295-317, 2003.

Jørgensen, B. B.: A comparison of methods for the quantification of bacterial sulfate reduction in coastal marine sediments, 1 . Measurement with radiotracer techniques, Geomicrobiol. J., 1, 11$28,1978$.

Jørgensen, B. B.: Mineralization of organic matter in the sea bed the role of sulphate reduction, Nature, 296, 643-645, 1982.

Jørgensen, B. B.: Bacteria and marine biogeochemistry,in:Marine Geochemistry, edited by: Schulz, H. D. and Zabel, M., SpringerVerlag, Berlin, Heidelberg, NY, 169-206, 2006.

Jørgensen, B. B. and Kasten, S.: Sulfur cycling and methane oxidation, in: Marine Geochemistry, edited by: Schulz, H. D. and Zabel, M., Springer-Verlag, Berlin, Heidelberg, NY, 271-309, 2006.

Jørgensen, B. B. and Revsbech, N. P.: Diffusive boundary layers and the oxygen uptake of sediments and detritus, Limnol. Oceanogr., 30, 111-122, 1985.

Kang, D. J., Lee, D. S., and Kim, K.-R.: The East Sea (Sea of Japan), in: Carbon and nutriet fuxes in continental margins, edited by: Liu, K.-K., Atkinson, L., Quiñones, R. A., and TalaueMaManus, L., Springer-Verlag, Berlin, Heidelberg, 383-394, 2010.

Kim, D., Choi, M.-S., Oh, H.-Y., Kim, K. H., and Noh, J.-H.: Estimate of particulate organic carbon export flux using ${ }^{234} \mathrm{Th} /{ }^{238} \mathrm{U}$ disequilibrium in the southwestern East Sea during summer, (The Sea) J. Korean Soc. Oceanogr., 14, 1-9, 2009.

Kim, D., Yang, E. J., Kim, K. H., Shin, C.-W., Park, J., Yoo, S. J., and Hyun, J.-H.: Impact of an anticyclonic eddy on the summer nutrient and chlorophyll a distributions in the Ulleung Basin, East Sea (Japan Sea), ICES J. Mar. Sci., 69, 23-29, 2012.

Kim, K., Kim, K.-R., Min, D. H., Volkov, Y., Yoon, J.-H., and Takematsu, M.: Warming and structural changes in the East Sea (Japan) Sea: a clue to future changes in the global oceans?, Geophys. Res. Lett., 28, 3293-3296, 2001.

Kostka, J. E., Luther, G. W., and Nealson, K. H.: Chemical and biological reduction of $\mathrm{Mn}(\mathrm{III})$-pyrophosphate complexes - potential importance of dissolved $\mathrm{Mn}(\mathrm{III})$ as an environmental oxidant, Geochim. Cosmochim. Ac., 59, 885-894, 1995.

Kostka, J. E., Thamdrup, B., Glud, R. N., and Canfield, D. E.: Rates and pathways of carbon oxidation in permanently cold Arctic sediments, Mar. Ecol.-Prog. Ser., 180, 7-21, 1999.

Kostka, J. E., Gribsholt, B., Petrie, E., Dalton, D., Skelton, H., and Kristensen, E.: The rates and pathways of carbon oxidation in bioturbated saltmarsh sediments, Limnol. Oceanogr., 47, 230240, 2002a.

Kostka, J. E., Roychoudhury, A., and Van Cappellen, P.: Rates and controls of anaerobic microbial respiration across spatial and temporal gradients in saltmarsh sediments, Biogeochemistry, 60, 49-76, 2002b.

Kwak, J. H., Hwang, J., Choy, E. J., Park, H. J., Kang, D.-J., Lee, T., Chang, K.-I., Kim, K.-R., and Kang, C.-K.: High primary productivity and f-ratio in summer in the Ulleung Basin of the East/Japan Sea, Deep-Sea Res. Pt. I, 79, 74-85, 2013. 
Lee, J.: Importance of nitrate reduction in coastal and deep-sea sediments, MS thesis, Department of Marine Science Graduate School, Pusan National University, Korea, 86 pp., 2009.

Lee, T., Hyun, J.-H., Mok, J. S., and Kim, D.: Organic carbon accumulation and sulfate reduction rates in slope and basin sediments of the Ulleung basin, East/Japan Sea, Geo.-Mar. Lett., 28, 153159, 2008.

Li, Y. H. and Gregory, S.: Diffusion of ions in sea water and deep sea sediments, Geochim. Cosmochim. Ac., 38, 703-714, 1974.

Liu, K.-K., Atkinson, L., Quiñones, R. A., and Talaue-MaManus, L.: Biogeochemistry of the continental margins, in: Carbon and nutriet fuxes in continental margins, edited by: Liu, K.-K., Atkinson, L., Quiñones, R. A., and Talaue-MaManus, L., SpringerVerlag, Berlin, Heidelberg, 3-24, 2010.

Lovley, D. R. and Phillips, E. J. P.: Manganese inhibition of microbial iron reduction in anaerobic sediments, Geomicrobiol. J., 6, 145-155, 1988.

Luther III, G. W.: Acid volatile sulfide - A comment, Mar. Chem., 97, 198-205, 2005.

Macdonald, R. W. and Gobeil, C.: Manganese sources andsinks in the Arctic Oceanwith reference to periodicenrichments in basin sediments, Aquat. Geochem., 18, 565-591, 2012.

Madison, S., Tebo, B. M., Mucci, A., Sundby, B., and Luther III, G. W.: Abundant porewater $\mathrm{Mn}(\mathrm{III})$ is a major component of the sedimentary redox system, Science, 341, 875-878, 2013.

Magen, C., Mucci, A., and Sundby, B.: Reduction rates of sedimentary $\mathrm{Mn}$ and Fe oxides: an incubation experiment with Arctic Ocean sediments, Aquat. Biogeochem., 17, 629-643, 2011.

Melton, E. D., Swanner, E. D., Behrens, S., Schmidt, C., and Kappler, A.: The interplay of microbially mediated and abiotic reactions in the biogeochemical Fe cycle, Nat. Rev. Microbiol., 12, 797-808, 2014.

Mewes, K., Mogollón, J. M., Picard, A., Rühlemann, C., Kuhn, T., Nöthen, K., and Kasten, S.: Impact of depositional and biogeochemical processes on small scale variations in nodule abundance in the Clarion-Clipperton Fracture Zone, Deep-Sea Res. Pt. I, 91, 125-141, 2014.

Mewes, K., Mogollón, J. M., Picard, A., Rühlemann, C., Eisenhauer, A., Kuhn, T., Ziebis, W., and Kasten, S.: Diffusive transfer of oxygen from seamount basaltic crust into overlying sediments: an example from the Clarion-Clipperton Fracture Zone, Earth Planet. Sc. Lett., 433, 215-225, 2016.

Meyers, C. and Nealson, K. H.: Microbial reduction of manganese oxides: Interactions with iron and sulfur, Geochim. Cosmochim. Ac., 52, 2727-2732, 1988.

Mogollón, J. M., Mewes, K., and Kasten, S.: Quantifying manganese and nitrogen cycle coupling in manganese-rich, organic carbon-starved marine sediments: examples from the ClarionClipperton fracture zone, Geophys. Res. Lett., 43, 7114-7123, doi:10.1002/2016GL069117, 2016.

Mouret, A., Anschutz, P., Lecroart, P., Chaillou, G., Hyacinthe, C., Deborde, J., Jorissen, F., Deflandre, B., Schmidt, S., and Jouanneau, J.-M.: Benthic geochemistry of manganese inthe Bayof Biscay, and sediment mass accumulation rate, Geo.-Mar. Lett. 29, 133-149, 2009.

Murray, J. W., Balistrieri, L. S., and Paul, B.: The oxidation stateof manganese in marinesediments and ferromanganesenodules, Geochim. Cosmochim. Ac., 48, 1237-1247, 1984.
Nickel, M., Vandieken, V., Brüchert, V., and Jørgensen, B. B.: Microbial $\mathrm{Mn}(\mathrm{IV})$ and $\mathrm{Fe}(\mathrm{III})$ reduction in northern Barents Sea sediments under different conditions of ice cover and organic carbon deposition, Deep-Sea Res. Pt. II, 55, 2390-2398, 2008.

Parsons, T. R., Maita, Y., and Lalli, C. M. (Eds.): A manual of chemical and biological methods for seawater analysis, Pergamon Press, Oxford, 173 pp., 1984.

Phillips, E. J. P. and Lovley, D. R.: Determination of Fe(III) and $\mathrm{Fe}(\mathrm{II})$ in oxalate extracts of sediment, Soil Sci. Soc. Am. J., 51, 938-941, 1987.

Postma, D.: Concentration of Mn and separation from Fe in sediments - I. Kinetics and stoichiometry of the reaction between birnessite and dissolved $\mathrm{Fe}(\mathrm{II})$ at $10^{\circ} \mathrm{C}$, Geochim. Cosmochim. Ac., 49, 1023-1033, 1985.

Pyzik, A. E. and Sommer, S. E.: Sedimentary iron monosulfide: kinetics and mechanisms of formation, Geochim. Cosmochim. Ac., 45, 687-698, 1981.

Rasmussen, H. and Jørgensen, B. B.: Microelectrode studies of seasonal oxygen uptake in a coastal sediment: role of molecular diffusion, Mar. Ecol.-Prog. Ser., 81, 289-303, 1992.

Rickard, D. and Morse, J. W.: Acid volatile sulfur (AVS), Mar. Chem., 97, 141-107, 2005.

Romankevich, E. A.: Geochemistry of organicmatter in the ocean, Springer-Verlag, Berlin, Heidelberg, NY, Tokyo, 334 pp., 1984.

Schaller, T. and Wehrli, B.: Geochemical-focusing of manganese in lake sediments - An indicator of deep-water oxygen conditions, Aquat. Geochem., 2, 359-378, 1997.

Schulz, H. D.: Qunatification of early diagenesis: dissolved constituents in marine pore water, in: Marine Geochemistry, edited by: Schulz, H. D. and Zabel, M., Springer-Verlag, Berlin, Heidelberg, NY, 169-206, 2006.

Slomp, C. P., Mort, H. P., Jilbert, T., Reed, D. C., and Gustafsson, B. G.: Coupled dynamics of iron and phosphorus in sediments of an oligotrophic coastal bsin and the impact of anaerobic oxidation of methane, PLoS ONE, 8, e62386, doi:10.1371/journal.pone.0062386, 2013.

Sørensen, J. W. and Jørgensen, B. B.: Early diagenesis in sediments from Danish coastal waters: Microbial activity and Mn-Fe-S geochemistry, Geochim. Cosmochim. Ac., 51, 1583-1590, 1987.

Sørensen, J. W., Jørgensen, B. B., and Revsbech, N. P.: A comparison of oxygen, nitrate and sulfate respiration in a coastal marine sediment, Microbiol. Ecol., 5, 105-115, 1979.

Stookey, L. L.: Ferrozine - a new spectrophotometric reagent for iron, Anal. Chem., 42, 779-781, 1970.

Sundby, B. and Silverberg, N.: Manganese fluxes in the benthic boundary layer, Limnol. Oceanogr., 30, 372-381, 1985.

Thamdrup, B.: Bacterial manganese and iron reduction in aquatic sediments, Adv. Microb. Ecol., 16, 41-84, 2000.

Thamdrup, B. and Canfield, D. E.: Pathways of carbon oxidation in continental margin sediments off central Chile, Limnol. Oceanogr., 41, 1629-1650, 1996.

Thamdrup, B. and Dalsgaard, T.: The fate of ammonium in anoxic manganese oxide-rich marine sediment, Geochim. Cosmochim. Ac., 64, 4157-4164, 2000.

Thamdrup, B., Rosselló-Mora, R., and Amann, R.: Microbial manganese and sulfate reduction in Black Sea shelf sediments, Appl. Environ. Microbiol., 66, 2888-2897, 2000.

Trimmer, M. and Engström, P.: Distribution, activity, and ecology of anammox bacteria in aquatic environments, in: Nitrification, 
edited by: Ward, B. B., Arp, D. J., and Klotz, M. G., ASM Press, Washington, DC, 201-235, 2011.

Trimmer, M., Engström, P., and Thamdrup, B.: Stark contrast in denitrification and anammox across the deep Norwegian Trench in the Skagerrak, Appl. Environ. Microbiol., 79, 7381-7389, 2013.

Vandieken, V., Nickel, M., and Jørgensen, B. B.: Carbon mineralization in Arctic sediments northeast of Svalbard: Mn(IV) and $\mathrm{Fe}(\mathrm{III})$ reduction as principal anaerobic respiratory pathways, Mar. Ecol.-Prog. Ser., 322, 15-27, 2006.

Vandieken, V., Pester, M., Finke, N., Hyun, J.-H., Friedrich, M. W., Loy, A., and Thamdrup, B.: Identification of acetate-oxidizing manganese-reducing bacteria in three manganese oxide-rich marine sediments by stable isotope probing, ISME J., 6, 2078-2090, 2012.

Vandieken, V., Finke, N., and Thamdrup, B.: Hydrogen, acetate, and lactate as electron donors for microbial manganese reduction in a manganese-rich coastal marine sediment, FEMS Micribiol Ecol., 87, 733-745, 2014.
Walsh, J. J.: Importance of continental margins in the marine biogeochemical cycling of carbon and nitrogen, Nature, 350, 53-55, 1991.

Yamada, K., Ishizaka, J., and Nagata, H.: Spatial and temporal variability of satellite primary production in the Japan Sea from 1998 to 2002, J. Oceanogr., 61, 857-869, 2005.

Yin, J. H., Kajiwara, Y., and Fujii, T.: Distribution of transition elements in surface sediments of the southwestern margin of Japan Sea, Geochem. J., 23, 161-180, 1989.

Yoo, S. and Park, J. S.: Why is the southwest the most productive region of the East Sea/Sea of Japan?, J. Marine Syst., 78, 301315, 2009. 